\title{
Dominant Neuropeptide Cotransmission in Kisspeptin-GABA Regulation of GnRH Neuron Firing Driving Ovulation
}

\author{
ㅈichard Piet, ${ }^{\circledR}$ Bruna Kalil,^ Tim McLennan, Robert Porteous, Katja Czieselsky, and @Allan E. Herbison \\ Centre for Neuroendocrinology and Department of Physiology, University of Otago School of Biomedical Sciences, Dunedin 9054, New Zealand
}

\begin{abstract}
A population of kisspeptin-GABA coexpressing neurons located in the rostral periventricular area of the third ventricle (RP3V) is believed to activate gonadotropin-releasing hormone $(\mathrm{GnRH})$ neurons to generate the luteinizing hormone (LH) surge triggering ovulation.

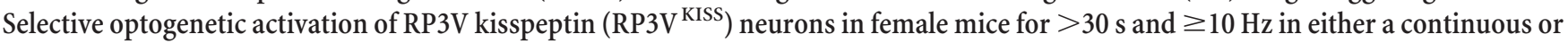
bursting mode was found to reliably generate a delayed and long-lasting activation of GnRH neuron firing in brain slices. Optogenetic activation of RP3V ${ }^{\mathrm{KISS}}$ neurons in vivo at $10 \mathrm{~Hz}$ generated substantial increments in $\mathrm{LH}$ secretion of similar amplitude to the endogenous $\mathrm{LH}$ surge. Studies using $\mathrm{GABA}_{\mathrm{A}}$ receptor antagonists and optogenetic activation of $\mathrm{RP} 3 \mathrm{~V} \mathrm{GABA}\left(\mathrm{RP} 3 \mathrm{~V}^{\mathrm{GABA}}\right)$ neurons in vitro revealed that low-frequency $(2 \mathrm{~Hz})$ stimulation generated immediate and transient $\mathrm{GABA}_{\mathrm{A}}$ receptor-mediated increases in $\mathrm{GnRH}$ neuron firing, whereas higher frequencies $(10 \mathrm{~Hz})$ recruited the long-lasting activation observed following RP3V ${ }^{\mathrm{KISS}}$ neuron stimulation. In vivo, $2 \mathrm{~Hz}$ activation of RP3V $\mathrm{V}^{\mathrm{GABA}}$ neurons did not alter LH secretion, whereas $10 \mathrm{~Hz}$ stimulation evoked a sustained large increase in LH identical to RP3V ${ }^{\mathrm{KISS}}$ neuron activation. Optogenetic activation of RP3V $\mathrm{V}^{\mathrm{KISS}}$ neurons in which kisspeptin had been deleted did not alter LH secretion. These studies demonstrate the presence of parallel transmission streams from RP3V neurons to GnRH neurons that are frequency dependent and temporally distinct. This comprises a rapid and transient $\mathrm{GABA}_{\mathrm{A}}$ receptor-mediated activation and a slower onset kisspeptin-mediated stimulation of long duration. At the time of the LH surge, GABA release appears to be functionally redundant with the neuropeptide kisspeptin being the dominant cotransmitter influencing GnRH neuron output.
\end{abstract}

Key words: GABA; GnRH; hypothalamus; kisspeptin; optogenetics

Significance Statement

Miscommunication between the brain and ovaries is thought to represent a major cause of infertility in humans. Studies in rodents suggest that a population of neurons located in the rostral periventricular area of the third ventricle (RP3V) are critical for activating the gonadotropin-releasing hormone $(\mathrm{GnRH})$ neurons that trigger ovulation. The present study provides evidence that an RP3V neuron population coexpressing kisspeptin and GABA provides a functionally important excitatory input to $\mathrm{GnRH}$ neurons at the time of ovulation. This neural input releases GABA and/or kisspeptin in the classical frequency dependent and temporally distinct nature of amino acid-neuropeptide cotransmission. Unusually, however, the neuropeptide stream is found to be functionally dominant in activating $\mathrm{GnRH}$ neurons at the time of ovulation.

\section{Introduction}

Many central neurons use the cotransmission of classical smallmolecules as well as neuropeptide neurotransmitters to signal

\footnotetext{
Received March 11, 2018; revised April 30, 2018; accepted May 25, 2018.

Author contributions: R.P. and B.K. wrote the first draft of the paper; R.P. and A.E.H. designed research; R.P., B.K., T.M., R.P., and K.C. performed research; R.P., B.K., T.M., and A.E.H. analyzed data; A.E.H. wrote the paper.

This work was supported by the New Zealand Health Research Council, Department of Physiology, University of Otago and Grant 232700/2014-1 (CNPq, Brazil) awarded to B.K. We thank Bradford Lowell (Harvard Medical School), Ulrich Boehm (Saarland University), and William Colledge (University of Cambridge) for the generous provision of genetically manipulated mouse lines.

The authors declare no competing financial interests.

*R.P. and B.K. contributed equally to this work.

Correspondence should be addressed to Allan E. Herbison, Centre for Neuroendocrinology and Department of Physiology, University of Otago School of Biomedical Sciences, Dunedin 9054, New Zealand. E-mail: allan.herbison@otago.ac.nz.
}

within their networks (Jan and Jan, 1983; van den Pol, 2012; Tritsch et al., 2016). It remains, however, that the mechanisms and functions of cotransmission are poorly understood. Although early studies were able to establish some of the general principles underlying cotransmission (Jan and Jan, 1983; Lundberg and Hokfelt, 1983; Verhage et al., 1991; Burnstock, 2004), optogenetic approaches have now greatly facilitated the investigation of corelease within the CNS (Schöne and Burdakov, 2012). For example, using this approach, the frequency-dependent release and dynamics of glutamate-acetylcholine (Ren et al., 2011) and glutamate-orexin 
(Schöne et al., 2014) cotransmission have been described for specific neuronal phenotypes.

The hypothalamus represents a brain region particularly rich in neuropeptides with many cell types synthesizing multiple peptides alongside small-molecule transmitters (Campbell et al., 2017; Chen et al., 2017). Despite this extensive amino acid-neuropeptide coexpression, very little is known about the individual roles or interactions of coreleased transmitters. For example, the impact of the individual transmitters in arcuate nucleus AgRP-NPYGABA neurons controlling feeding and other behaviors remain unclear despite intense scrutiny (Atasoy et al., 2012; Krashes et al., 2013; Padilla et al., 2016; Rau and Hentges, 2017). Whereas fast GABA release is always found to be functionally important, the contribution of neuropeptides to the various roles of AgRP-NPYGABA neuron is often uncertain (Tong et al., 2008; Atasoy et al., 2012; Krashes et al., 2013; Padilla et al., 2016).

The kisspeptin neurons located in the rostral periventricular area of the third ventricle (RP3V) are another hypothalamic cell population expressing multiple transmitters (Semaan et al., 2010; Clarkson and Herbison, 2011; Cravo et al., 2011; Porteous et al., 2011; Skrapits et al., 2015). These cells are believed to provide direct excitatory inputs to gonadotropin-releasing hormone $(\mathrm{GnRH})$ neurons to initiate the luteinizing hormone (LH) surge and, consequently, ovulation (Smith et al., 2006; Herbison, 2016). Coexpression studies have variously reported that $20-75 \%$ of RP3V kisspeptin (RP3V $\mathrm{V}^{\mathrm{KISS}}$ ) neurons are GABAergic (Cravo et al., 2011; Cheong et al., 2015) suggesting that RP3V neurons can signal through both GABA and kisspeptin to regulate the activity of the GnRH neurons (Herbison and Moenter, 2011; Piet et al., 2015b). Substantial evidence supports a role for kisspeptin in activating GnRH neurons at the time of the LH surge (Herbison, 2016). For example, RP3V ${ }^{\mathrm{KISS}}$ neurons project directly to GnRH neurons (Yip et al., 2015) and are known to be activated at the time of the LH surge (Smith et al., 2006; Clarkson et al., 2008). In contrast, a role for $\mathrm{GABA}_{\mathrm{A}}$ receptor signaling in surge generation has long been suspected but remains unproven (Herbison, 2015). Unusually within the forebrain, $\mathrm{GABA}_{\mathrm{A}}$ receptor activation is depolarizing in adult GnRH neurons (Herbison and Moenter, 2011).

In the present investigation, we have used cell-type-specific optogenetic activation of RP3V GABA (RP3V ${ }^{\mathrm{GABA}}$ ) and RP3V $\mathrm{V}^{\mathrm{KISS}}$ neurons to examine their ability to activate $\mathrm{GnRH}$ neurons and stimulate LH secretion. Due to the coexpression of kisspeptin and GABA in RP3V neurons we also questioned the role of GABAkisspeptin cotransmission from these cells to the GnRH neurons in vitro and in vivo. We report the existence of frequencymodulated and temporally distinct neuropeptide and GABA cotransmission streams from the RP3V to the GnRH neuron. Although GABA release from RP3V neurons is shown to modulate GnRH neuron firing, this is not found to be influential in vivo where, unusually, it is the neuropeptide signaling that governs functional output at that time of the LH surge.

\section{Materials and Methods}

Animals, stereotaxic AAV injections, and surgery. Adult female Kiss1IRES-Cre $^{+/-}$(Mayer et al., 2010), Kiss1-Cre ${ }^{+++}$(Yeo et al., 2016), Kiss1-IRES-Cre ${ }^{+-}$;GnRH-GFP ${ }^{+/-}$(Spergel et al., 1999), vGAT-IRES-Cre ${ }^{+/-}$ (RRID:IMSR_JAX:028862; Vong et al., 2011), vGAT-IRES-Cre ${ }^{+/-}$; tau-GFP reporter (Wen et al., 2011), and vGAT-IRES-Cre ${ }^{+/-}$;GnRH$\mathrm{GFP}^{+/-}$mice were group-housed under conditions of controlled temperature $\left(22 \pm 2^{\circ} \mathrm{C}\right)$ and lighting $(12 \mathrm{~h}$ light/ dark cycle; lights on at 6:00 $\mathrm{h}$ and off at 18:00 h) with ad libitum access to food and water. The University of Otago Animal Ethics Committee approved all animal experimental protocols.
Mice were anesthetized with Isoflurane, placed in a stereotaxic apparatus and given unilateral or bilateral $0.5-1 \mu \mathrm{l}$ injections of AAV9EF1-dflox-hChR2-(H134R)-mCherry-WPRE-hGH $\left(2.2 \times 10^{13} \mathrm{GC} / \mathrm{ml}\right.$; Penn Vector Core) into the RP3V (coordinates according to the Paxinos Brain Atlas, $0.8 \mathrm{~mm}$ anterior to bregma and $4.8 \mathrm{~mm}$ in depth) at a rate of $100 \mathrm{nl} / \mathrm{min}$. The syringes were left in situ for $3 \mathrm{~min}$ before and $10 \mathrm{~min}$ after the injections.

Gonadal steroid induction of the LH surge. Following a recovery period of $>3$ weeks, mice were anesthetized with Isoflurane and bilaterally ovariectomized and given an estradiol replacement regimen $(\mathrm{OVX}+\mathrm{E})$ that generates a GnRH/LH surge (Czieselsky et al., 2016). Subcutaneous SILASTIC capsules were prepared according to Bronson and Vom Saal (1979) by injecting $17-\beta$-estradiol mixed with medical grade adhesive $(0.1 \mathrm{mg} / \mathrm{ml}$ adhesive) into SILASTIC tubing (internal diameter $1.0 \mathrm{~mm}$, external diameter $2.13 \mathrm{~mm})$. When set, the tubing is cut to size $(1 \mathrm{~cm} / 20$ g body weight) to generate capsules that provide $1 \mu \mathrm{g}$ estradiol $/ 20 \mathrm{~g}$ body weight. Six days later, mice received a subcutaneous injection of estradiol benzoate ( $1 \mu \mathrm{g} / 20 \mathrm{~g}$ body weight) in the morning and were used for experiments the following day when an LH surge commences at 17:30 h and peaks $90 \mathrm{~min}$ later (Czieselsky et al., 2016).

Immunohistochemistry. Mice were killed by anesthetic overdose and perfused through the heart with $4 \%$ paraformaldehyde. Three sets of 30$\mu \mathrm{m}$-thick coronal brain sections were cut through the rPOA and processed for free-floating kisspeptin immunofluorescence using a well characterized (Clarkson et al., 2009b) polyclonal rabbit anti-kisspeptin antiserum (1:2000, AC566; gift from Dr. Alain Caraty, Nouzilly, France; RRID:AB_2622231), biotinylated goat anti-rabbit secondary immunoglobulins (1:200; Vector Laboratories Inc.; RRID:AB_2313606) and streptavidin AlexaFluor 488 (Invitrogen; RRID:AB_2336881). Three sections at the level of the periventricular nucleus were analyzed in each mouse by counting the total number of cells expressing 488-immunofluorescence [kisspeptin] and/or mCherry [Channelrhodopsin-2 (ChR2)].

Brain slice preparation, light stimulation, and cell-attached recordings. Mice were killed by cervical dislocation, decapitated and their brains quickly removed at times indicated in each experimental section. Coronal brain slices (200-250 $\mu \mathrm{m}$ thick) including the rostral preoptic area (rPOA) and RP3V were cut with a vibratome (VT1000S, Leica) in an ice-cold solution containing the following (in $\mathrm{mM}$ ): $87 \mathrm{NaCl}, 2.5 \mathrm{KCl}, 25$ $\mathrm{NaHCO}_{3}, 1.25 \mathrm{NaH}_{2} \mathrm{PO}_{4}, 0.5 \mathrm{CaCl}_{2}, 6 \mathrm{MgCl}_{2}, 25$ glucose, and 75 sucrose. Slices were then incubated at $30 \mathrm{C}$ for at least $1 \mathrm{~h}$ in artificial CSF (aCSF) containing the following (in $\mathrm{mm}$ ): $120 \mathrm{NaCl}, 3 \mathrm{KCl}, 26 \mathrm{NaHCO}_{3}, 1$ $\mathrm{NaH}_{2} \mathrm{PO}_{4}, 2.5 \mathrm{CaCl}_{2}, 1.2 \mathrm{MgCl}_{2}$, and 10 glucose. All solutions were equilibrated with $95 \% \mathrm{O}_{2} / 5 \% \mathrm{CO}_{2}$. Slices were placed under an upright microscope fitted for epifluorescence (Olympus) and constantly perfused (1.5 $\mathrm{ml} / \mathrm{min})$ with warm $(\sim 30 \mathrm{C})$ aCSF. GFP-expressing GnRH neurons and mCherry-expressing RP3V neurons were first visualized by brief fluorescence illumination (excitation $460-480$ and $530-550 \mathrm{~nm}$, respectively) and subsequently approached using infrared differential interference contrast optics. Because the ChR2 excitation spectrum overlaps that of GFP, a waiting period of at least $15 \mathrm{~min}$ following fluorescent identification of a GFP-expressing neuron was allowed before starting any electrophysiological recording.

Action potential firing was recorded in voltage-clamp mode in the cell-attached loose-patch configuration. Recording electrodes (3-5 M $\Omega$ ) pulled from borosilicate capillaries (Warner Instruments) with a horizontal puller (Sutter Instruments) were filled with aCSF including $10 \mathrm{~mm}$ HEPES. Low resistance seals (10-30 M $\Omega$ ) were achieved by applying either no suction or the lowest amount of suction required to detect spikes. For ChR2 activation, blue light was delivered to the slice through a $40 \times$ immersion objective ( $0.8 \mathrm{NA}$, Olympus) via a $470 \mathrm{~nm}$ light emitting diode (CoolLED) connected to the vertical illumination port of the microscope. Stimulation consisted of trains of blue light pulses $(2 \mathrm{~ms}$ duration; $<1 \mathrm{~mW}$ ) delivered at $2-20 \mathrm{~Hz}$ for 5-300 s. Electrophysiological signals were recorded using a Multiclamp 700B amplifier (Molecular Devices) connected to a Digidata 1440A digitizer (Molecular Devices). Signals were low-pass filtered at $3 \mathrm{kHz}$ before being digitized at a rate of $10 \mathrm{kHz}$ and stored on a personal computer. Signal acquisition and analysis was performed with pClamp 10 (Molecular Devices; RRID:SCR_011323). Spikes were detected using the threshold crossing method. 

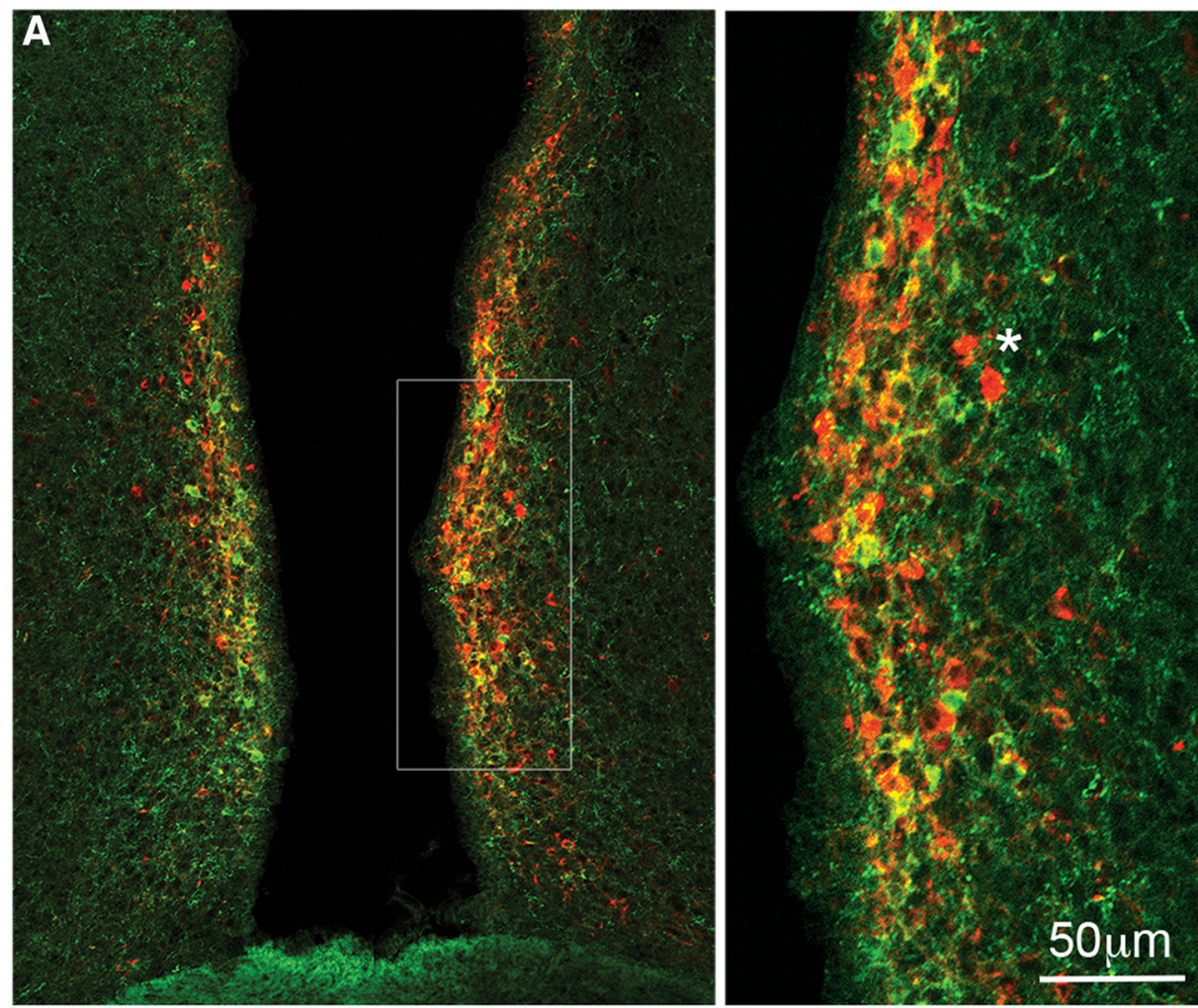

B
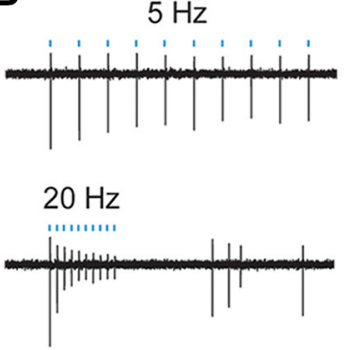

$40 \mathrm{~Hz}$

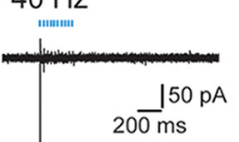

C

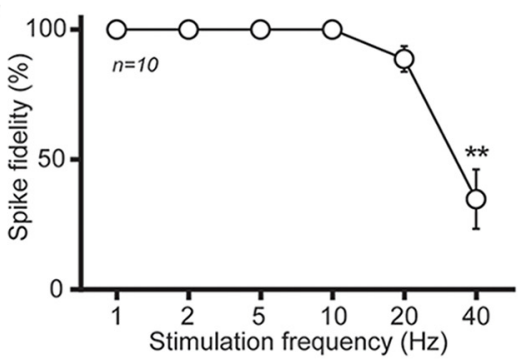

D $10 \mathrm{~Hz}$; continuous

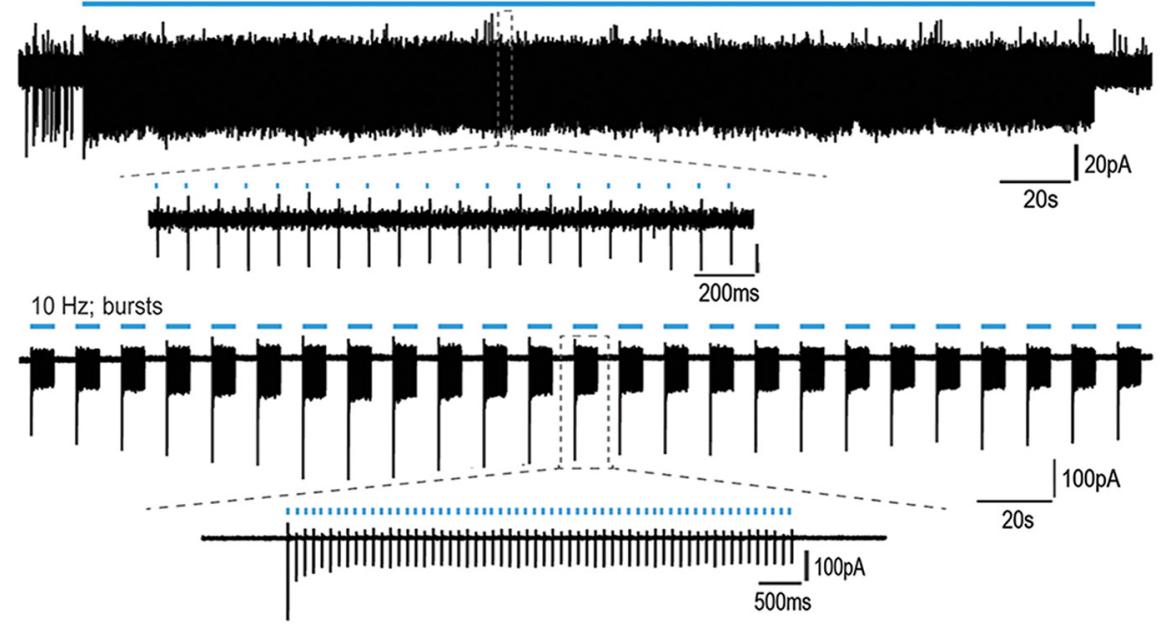

Figure 1. ChR2-mCherry control of RP3V KISS neuron firing. $A$, Dual immunofluorescence showing kisspeptin (green), mCherry (red), and dual-labeled (yellow/orange) cells in the RP3V of an AAV-ChR2-mCherry injected Kiss7-IRES-Cre mouse. Inset (expanded to right), The relative intensities of the GFP and mCherry result in many cells being orange. An asterisk indicates two cells expressing only mCherry for reference. $\boldsymbol{B}$, Example traces illustrating the response of an RP3V ${ }^{\mathrm{KISS}}$ neuron to trains of 10 blue-light pulses delivered at 5, 10, 20 and 40 Hz. $C$, Summary graph of spike fidelity as a function of stimulation frequency in 10 different RP3V KISS neurons. Spike fidelity significantly decreases at $40 \mathrm{~Hz}\left({ }^{* *} p<0.01\right)$. D. Example traces illustrating the response of RP3V KISS neurons to a 5 min blue light stimulation train at $10 \mathrm{~Hz}$ (continuous) and to burst stimulation (60 pulses at $10 \mathrm{~Hz}$ every $12 \mathrm{~s}$ ) delivered over 5 min (bursts). Insets, Individual spikes at expanded timescales. 
Electrophysiology analysis. For ChR2-expressing RP3V ${ }^{\mathrm{KISS}}$ and RP3V ${ }^{\mathrm{GABA}}$ neurons, spike fidelity was calculated by dividing the number of lightevoked spikes by the number of blue light stimuli and expressed as a percentage. In GnRH neurons, the effect of blue light stimulation in afferents was assessed over two different time periods: during the stimulation (immediate) and after the stimulation (delayed). As blue lightinduced immediate increases in firing were often transient, the GnRH neuron response to the first 60 stimuli were measured (first $30 \mathrm{~s}$ at $2 \mathrm{~Hz}$, first $6 \mathrm{~s}$ at $10 \mathrm{~Hz}$ ). Action potential frequency in $2 \mathrm{~s}$ bins was averaged across the 30 or 6 s immediately preceding the light train ("baseline") and during the first 30 or $6 \mathrm{~s}$ after the onset of the stimulation ("during train"), at 2 and $10 \mathrm{~Hz}$, respectively. Changes in firing were calculated by subtracting baseline from during train. For delayed effects, baseline was the average action potential frequency in $10 \mathrm{~s}$ bins across the $2 \mathrm{~min}$ immediately preceding the light train, whereas after train was the average action potential frequency across the $5 \mathrm{~min}$ immediately following the light train.

In vivo optogenetic experiments. Adult female kisspeptin-IRES-Cre ${ }^{+/-}$ and vGAT-IRES-Cre ${ }^{+/-}$mice were injected with AAV-ChR2 and given the same OVX and estrogen replacement regimen as detailed above. We also used Kiss1-Cre ${ }^{+/+}$mice in which kisspeptin is deleted from all Kiss1-expressing cells. This generates mice with an equivalent phenotype to the Kiss1-null mouse (Yeo et al., 2016). In the context of the present optogenetic studies this provides a useful model in which ChR2-expressing neurons no longer synthesize kisspeptin but do retain their other coexpressed neuropeptides and transmitters.

At $\sim 15: 00 \mathrm{~h}$ on the day of the expected LH surge, mice were anesthetized with isoflurane, placed in a stereotaxic apparatus and a $100-\mu \mathrm{m}-$ diameter optic fiber connected to a laser implanted unilaterally so as to sit immediately above the RP3V $(0.8 \mathrm{~mm}$ anterior to bregma, $0.3 \mathrm{~mm}$ lateral, $4.5 \mathrm{~mm}$ in depth). Ninety minutes later, the experimental protocol commenced by delivering $5 \mathrm{~ms} 470 \mathrm{~nm}$ wavelength light at frequencies of 2 or $10 \mathrm{~Hz}$ for 15 or $30 \mathrm{~min}$ ("continuous"), or $10 \mathrm{~Hz}$ for $6 \mathrm{~s}$ every $12 \mathrm{~s}$ over 30 min ("bursting") depending on experiment. For 15 min stimulations, serial blood samples $(5 \mu \mathrm{l})$ were collected from the tail tip at -5 , $0,5,10,15,30,45,60,75$, and $90 \mathrm{~min}$ where time 0 is the start of the optogenetic stimulation. For $30 \mathrm{~min}$ stimulations, blood samples were taken at $-5,0,5,10,15,20,25,30,45,60,75$, and 90 . The blood samples were processed for LH by ELISA as reported previously (Czieselsky et al., 2016).

Experimental design and statistical analysis. The sample size for each experiment is given in the Results. Values given in the text and illustrated in figures are mean \pm SEM. For electrophysiological studies, all experiments were replicated in at least three different mice in each group with, typically, two slices used from each mouse. Analyses were undertaken with repeated-measures ANOVA and post hoc Tukey's tests, as well as Kruskal-Wallis and Friedman tests as appropriate and stated for individual experiments. The number of animals is represented as " $N$ " and " $n$ " represents the number of cells. The analysis of $\mathrm{LH}$ values was undertaken using one-way repeated-measures ANOVA with post hoc Dunnett's multiple-comparison tests, comparing values to the -5 min LH level. For ANOVA, sphericity was not assumed and Greenhouse-Geisser corrections made. To compare between groups, statistical comparisons were made by two-way repeated-measures ANOVA. Data were analyzed using Prism 6 (GraphPad Software; RRID:SCR_002798) and reported as mean \pm SEM. $p$ values are rounded to three decimal places and values $<0.001$ are reported as $p<0.001$. Statistical tests were undertaken as dictated by the nature of the experiment and are explained in each section of the Results. All statistical parameters are reported for each experiment in the Results. Significance was set at $p<0.05$.

\section{Results}

\section{RP3V ${ }^{\mathrm{KISS}}$ neuron regulation of GnRH neurons}

Characterization of ChR2 expression in RP3V $V^{\text {KISS }}$ neurons

ChR2 fused with mCherry was targeted to RP3V $\mathrm{V}^{\mathrm{KISS}}$ neurons by injecting AAV9-EF1-dflox-hChR2-(H134R)-mCherry-WPREhGH bilaterally into the RP3V of female Kiss1-IRES-Cre mice. Two weeks after AAV injections, mice were given a $7 \mathrm{~d} O V X+E$ regimen and killed on the day of the expected LH surge by anesthetic overdose followed by perfusion fixation. Kisspeptin-immunoreactive cell bodies were located in their normal distribution (Fig. $1 A)$ with $26.1 \pm 2.6$ kisspeptin-immunoreactive cells detected per 30- $\mu \mathrm{m}$-thick hemisection at the level of the periventricular nucleus $(N=4)$. Dual-label kisspeptin/mCherry cells were located throughout the rostrocaudal extent of the RP3V with $61.7 \pm 6.1 \%$ kisspeptin neurons expressing $\mathrm{ChR} 2$, accounting for $59.8 \pm 5.8 \%$ of all ChR2 neurons in the RP3V $(N=4$; Fig. $1 A)$. The relatively low percentage of ChR2 cells with kisspeptin fluorescence likely reflects the relative insensitivity of the immunofluorescence to detect all kisspeptin neurons (Clarkson et al., 2009a). Control AAV injections performed in wild-type mice $(N=3)$ resulted in no mCherry expression confirming the Cre dependence of the viral vector.

\section{Optogenetic activation of RP3V $V^{\text {KISS }}$ neurons in vitro}

To assess the ability of ChR2 to control the firing of RP $3 \mathrm{~V}^{\mathrm{KISS}}$ neurons, coronal brain slices containing the RP3V were prepared from AAV-injected OVX+E Kiss1-IRES-Cre mice killed on the day of the expected LH surge. The action potential firing of $\mathrm{RP} 3 \mathrm{~V}^{\mathrm{KISS}}$ neurons was recorded by making cell-attached recordings from mCherry-expressing cells and blue light ( $470 \mathrm{~nm}, 2 \mathrm{~ms}$ ) delivered to the slice at $1,2,5,10,20$, and $40 \mathrm{~Hz}$ (10 pulses per train). RP3V $\mathrm{V}^{\mathrm{KISS}}$ neurons exhibited action potentials in response to blue light activation with high fidelity (Fig. 1B). Stimulation at $1-10 \mathrm{~Hz}$ induced action potentials with $100 \%$ fidelity while frequencies of 20 and $40 \mathrm{~Hz}$ generated $89 \pm 5$ and $35 \pm 11 \%$ fidelity, respectively ( $n=10$ cells, 4 mice; Fig. $1 C$ ). The response at $40 \mathrm{~Hz}$ stimulation was significantly reduced compared with other frequencies (repeated-measures ANOVA $F_{(5,45)}=28.54, p<0.001$, post hoc Tukey's tests; Fig. 1C). These data show that ChR2expressing RP3V KISS neurons can faithfully follow blue light activation up to moderately high stimulation frequencies. Many $\mathrm{RP} 3 \mathrm{~V}^{\mathrm{KISS}}$ neurons in proestrous female mice fire action potentials in a bursting pattern that, although variable between cells, often appears as periods of firing with similar on and off intervals (de Croft et al., 2012; Piet et al., 2015a). As such, we were interested in examining the effects of patterned "bursting" activation of ChR2-expressing RP3V ${ }^{\mathrm{KISS}}$ neuron and chose to use $10 \mathrm{~Hz}$ stimulation with $6 \mathrm{~s}$ on, $6 \mathrm{~s}$ off, for $5 \mathrm{~min}$. ChR2-expressing $\mathrm{RP} 3 \mathrm{~V}^{\mathrm{KISS}}$ neurons responded with near-perfect fidelity of $99 \pm$ $0.1 \%$ and $99 \pm 1 \%$ to both continuous $(10 \mathrm{~Hz}$ for $5 \mathrm{~min})$ and bursting $(5 \mathrm{~min})$ patterns of blue light activation $(n=6,4$ and 3 mice, respectively; Fig. 1D).

\section{Optogenetic activation RP3V $V^{\text {IISS }} \rightarrow$ GnRH neuron pathway in vitro} Coronal brain slices containing the $\mathrm{rPOA}$ were prepared from AAV-injected OVX+E Kiss1-IRES-Cre; GnRH-GFP mice killed between 11:00-13:00 $\mathrm{h}$ to ensure that the responses of GnRH neurons are examined on the afternoon of the expected $\mathrm{GnRH} / \mathrm{LH}$ surge. These slices include the somata and proximal dendrites of GFP-expressing GnRH neurons, alongside the projections of ChR2-expressing RP3V ${ }^{\mathrm{KISS}}$ neurons (Fig. $2 A, B$ ).

We first investigated the effect of trains of $470 \mathrm{~nm}$ light stimulation on the electrical activity of GFP-expressing GnRH neurons. Blue light elicited a delayed, reversible increase in action potential firing that greatly outlasted the duration of the stimulation (Fig. 2C). Overall, 69 of $97 \mathrm{GnRH}$ neurons (71\%) increased their firing in response to blue light stimulation while a minority of GnRH neurons (29\%) were not affected (Fig. 2D). We next observed the dependence of these responses upon stimulation frequency by delivering trains of 300 blue light pulses at various rates. Of the 

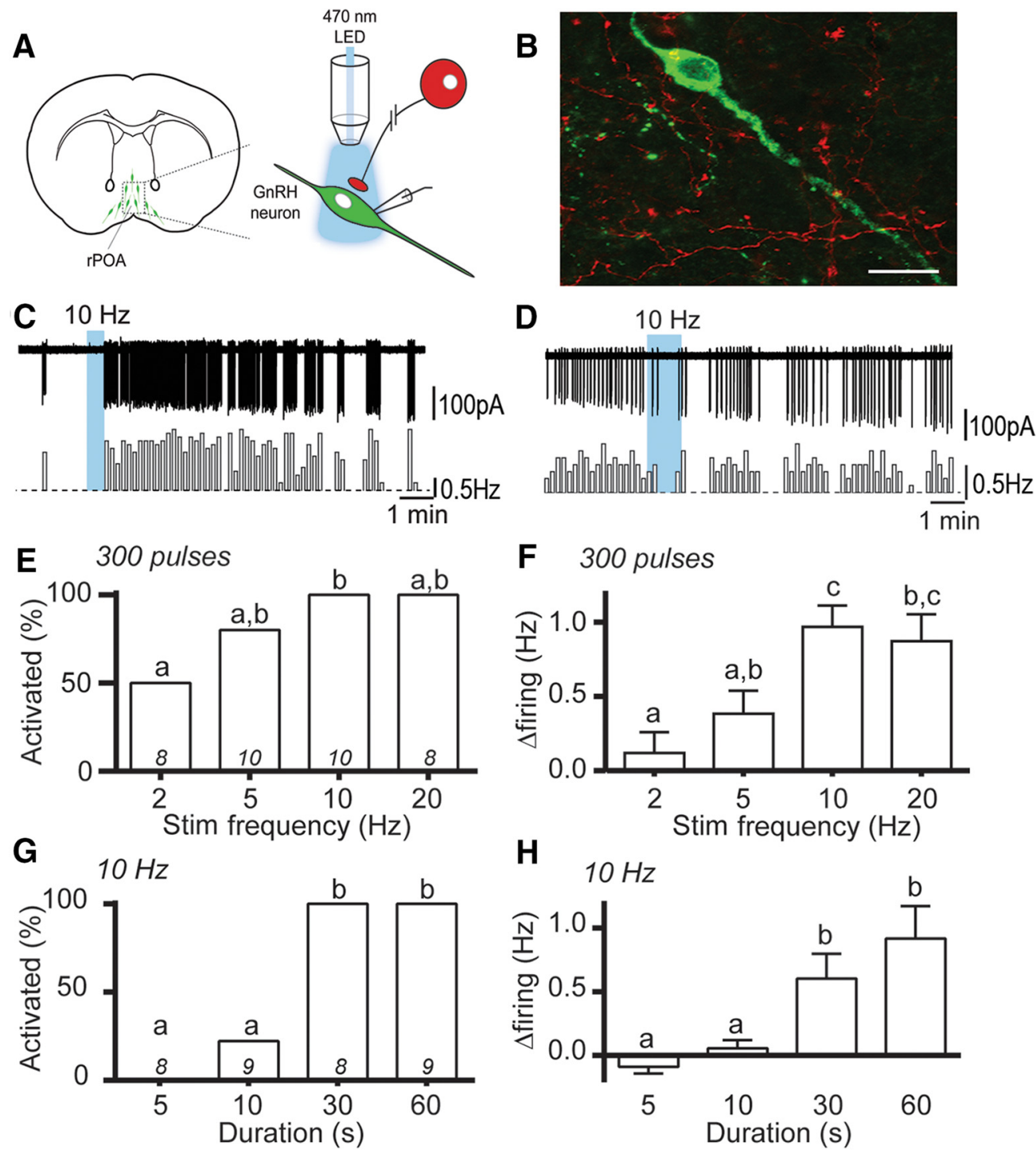

Figure 2. Optogenetic activation of RP3V KISS neuron axons excites GnRH neurons. $A$, Schematic representation of optogenetic brain slice experiment. $\boldsymbol{B}$, Photomicrograph showing a GnRH-GFP neuron surrounded by RP3V origin mCherry-positive fibers opposing its cell body and primary dendrite (yellow overlap). $\boldsymbol{C}, \mathbf{D}$, Example traces and corresponding rate meters below (10 s bins) of GnRH neurons that increased its firing rate $(\boldsymbol{C})$ or was unaffected $(\boldsymbol{D})$ by $10 \mathrm{~Hz}$ blue-light stimulation of RP3V ${ }^{\mathrm{KISS}}$ neuron axons. $\boldsymbol{E}, \boldsymbol{F}$, Increasing stimulation frequency, with a constant number of pulses, increases the proportion of responding $\mathrm{GnRH}$ neurons $(\boldsymbol{E})$ and the magnitude of their responses $(\boldsymbol{F}), \mathbf{G}, \boldsymbol{H}$, Increasing the stimulus duration, at $10 \mathrm{~Hz}$, increases the proportion of excited $\mathbf{G n R H}$ neurons $(\boldsymbol{G})$ and the magnitude of their responses $(\boldsymbol{H})$. Bars with differing letters are significantly $(p<0.05)$ different to each other.

GnRH neurons exhibiting an increase in firing in response to 10 or $20 \mathrm{~Hz}, 80 \%$ and $50 \%$ responded to a stimulation delivered at 5 and 2 $\mathrm{Hz}$, respectively ( $p=0.023,2$ vs $10 \mathrm{~Hz}$, Fisher's exact test; Fig. $2 E$ ). Furthermore, the magnitude of GnRH neuron responses significantly increased with increasing stimulation frequencies [KruskalWallis test (14.18), $p=0.003$, post hoc Dunn's tests; $n=8-10,6-9$ mice; Fig. $2 F]$. We then varied the duration of blue light stimulation trains delivered at $10 \mathrm{~Hz}$. Of the $\mathrm{GnRH}$ neurons responding to a 30 or 60 s stimulation train, $22 \%$ were excited by a 10 s train while none were activated by a $5 \mathrm{~s}$ stimulation ( 5 and $10 \mathrm{~s}$ vs 30 and $60 \mathrm{~s}$, Fisher's exact test, all comparisons $p<0.002$; Fig. $2 G$ ). The GnRH neuron change in firing rate increased significantly with longer train durations ( $p<0.001$, Kruskal-Wallis (22.3) test, post hoc Dunn's tests; $n=8-9,6-7$ mice; Fig. $2 H)$.

We next compared the effectiveness of burst versus continuous $10 \mathrm{~Hz}$ activation of RP3V ${ }^{\mathrm{KISS}}$ neuron axons. The bursting paradigm ( 60 pulses at $10 \mathrm{~Hz}$ repeated 10 times every $12 \mathrm{~s}$ for 2 min; Fig. 3A) was found to be as effective as the continuous (600 pulses at $10 \mathrm{~Hz}$ for $1 \mathrm{~min}$; Fig. $3 B$ ) blue light stimulation in activating $\mathrm{GnRH}$ neurons [change in firing $0.71 \pm 0.36$ vs $0.68 \pm$ $0.39 \mathrm{~Hz}$; Wilcoxon test ( $\mathrm{W}=-4), p=0.81 ; n=7,6$ mice; Fig. $3 C, D]$, with a nonsignificant trend toward earlier activation observed with continuous stimulation (Fig. 3C).

Together, these findings revealed that the selective activation of RP3V $\mathrm{V}^{\mathrm{KISS}}$ neuron axonal projections provides a robust pathway for stimulating the firing of $\mathrm{GnRH}$ neurons. The activation of RP3V ${ }^{\text {KISS }}$ neuron axons at frequencies $\geq 10 \mathrm{~Hz}$ for $\geq 30 \mathrm{~s}$, delivered in either a continuous or bursting fashion, is sufficient to reliably evoke action potential firing in $\mathrm{GnRH}$ neurons.

\section{RP3V ${ }^{\text {GABA }}$ neuron regulation of GnRH neurons}

ChR2 control of RP3V GABA neurons

ChR2 was targeted to RP3V $V^{\text {GABA }}$ neurons by injecting the same AAV (AAV9-EF1-dflox-hChR2-(H134R)-mCherry-WPRE-hGH) unilaterally into the RP3V of female Vgat-Cre;tau-GFP reporter mice. Large numbers of mCherry-expressing cells were detected 

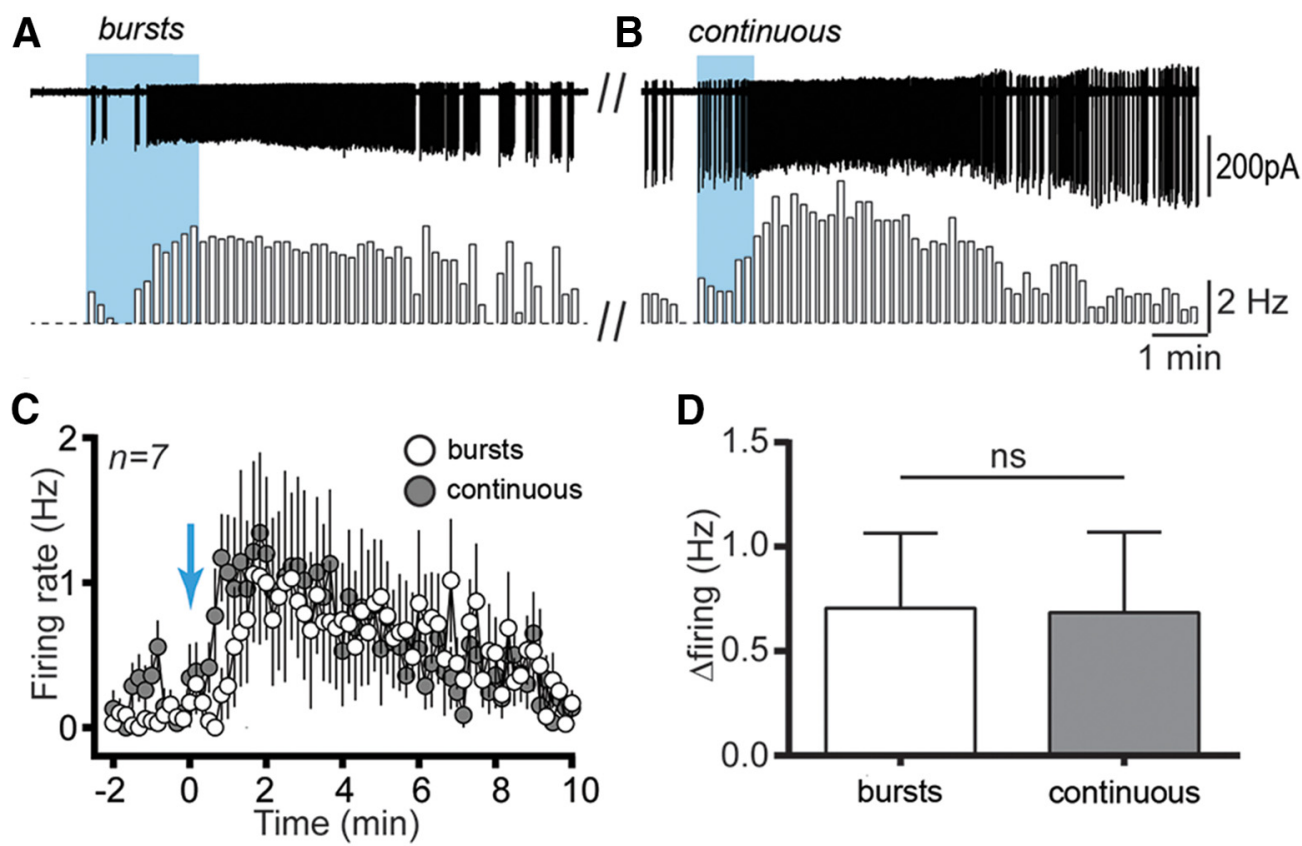

Figure 3. Continuous versus burst kisspeptin activation of $\mathrm{GnRH}$ neurons. $A, B$, Example traces and corresponding rate meters (10 s bins) showing a GnRH neuron response to 600 pulses delivered at $10 \mathrm{~Hz}$ either in bursts $(\boldsymbol{A})$ or continuously $(\boldsymbol{B})$. $\boldsymbol{C}$, The time course of averaged responses to burst (white circles) and continuous (gray circles) beginning at the blue arrow are shown for $7 \mathrm{GnRH}$ neurons. $\boldsymbol{D}$, The mean change in firing evoked by the two stimulation patterns is not significantly different.

within and lateral to the RP3V (Fig. 4A). However, even when amplified by immunofluorescence, the level of GFP expression was insufficient to unambiguously identify individual GFP-tagged GABA neurons and this precluded a quantitative assessment of mCherry expression in GABAergic neurons. No mCherry was found in AAV-injected wild-type littermates.

To assess the ability of ChR 2 to control the firing of RP $3 V^{\text {GABA }}$ neurons, coronal brain slices containing the RP3V were prepared from AAV-injected, OVX+E mice killed on the day of the expected LH surge. Following from the RP3V kisspeptin experiments, and previous observations (Liu et al., 2011), we chose to examine the effects of $2 \mathrm{~Hz}$ and $10 \mathrm{~Hz}$ optogenetic activation that we reasoned would evoke GABA alone $(2 \mathrm{~Hz})$ or GABA and neuropeptide $(10 \mathrm{~Hz})$ release from GABAergic neurons. Cell-attached recordings were made from mCherry-expressing RP3V ${ }^{\mathrm{GABA}}$ neurons and $470 \mathrm{~nm}$ light delivered at 2 or $10 \mathrm{~Hz}$ for 5 min (Fig. 4B). Spike fidelity was $100 \%$ with $2 \mathrm{~Hz}$ activation and $92 \pm 7 \%$ with $10 \mathrm{~Hz}(n=$ 5, 3 mice; Fig. $4 B)$.

\section{Optogenetic activation $R P 3 V^{G A B A} \rightarrow G n R H$ neuron pathway} in vitro

Coronal brain slices containing the rPOA were prepared from AAV-injected OVX+E Vgat-Cre; GnRH-GFP mice killed between 11:00-13:00 h on the day of the expected LH surge. The effects of 600 light pulses given at $2 \mathrm{~Hz}(5 \mathrm{~min})$ or $10 \mathrm{~Hz}(1 \mathrm{~min})$ on $\mathrm{GnRH}$ neuron firing were determined. Optogenetic activation of rPOA ChR2-expressing GABAergic fibers could evoke an immediate increase in GnRH neuron action potential firing during the stimulation and/or a delayed and prolonged increase in firing that outlasted the period of stimulation (Fig. $5 A, B$ ).

Activating ChR2-expressing axons at $2 \mathrm{~Hz}$ caused an "immediate only" response in 11 of 31 (35\%) GnRH neurons (7 mice), a "delayed only" response in 7 (23\%) GnRH neurons (5 mice) and both an immediate and delayed response in $2 \mathrm{GnRH}$ neurons (7\%; Fig. 5A). The remaining 11 (35\%) GnRH neurons (8 mice) did not show any response to $2 \mathrm{~Hz}$ activation. When $10 \mathrm{~Hz}$ bluelight stimuli were applied to rPOA slices, 6 of 33 (18\%) GnRH neurons ( 5 mice) exhibited an immediate only response, 10 (30\%; 6 mice) showed a delayed only rise in firing frequency and $13 \mathrm{GnRH}$ neurons (39\%, 8 mice) exhibited both types of responses (Fig. 5B). Four of 33 (12\%) GnRH neurons showed no response to blue light stimulation.

The overall percentage of GnRH neurons exhibiting the immediate increases in firing was similar between 2 and $10 \mathrm{~Hz}$ stimulations (42 and 58\%, respectively, $p=0.31$ Fisher's exact test) although the magnitude of the effect was larger at $10 \mathrm{~Hz}$ compared with $2 \mathrm{~Hz}(1.82 \pm 0.48$ vs $0.32 \pm 0.24 \mathrm{~Hz}$, Mann-Whitney $U$ test, $p=0.017$; Fig. $5 C$ ). In contrast, the delayed increases in firing were found more often with $10 \mathrm{~Hz}$ (70\% GnRH neurons) than $2 \mathrm{~Hz}(29 \%)$ stimulations ( $p=0.002$ Fisher's exact test) and the $10 \mathrm{~Hz}$ activations evoked significantly larger increases in firing than $2 \mathrm{~Hz}$ activations $(0.44 \pm 0.12$ vs $0.11 \pm 0.09 \mathrm{~Hz}$, respectively; Mann-Whitney test, $p=0.008$; Fig. $5 D)$.

To examine the degree to which $\mathrm{GABA}_{\mathrm{A}}$ receptor signaling was contributing to these responses, the effects of pretreatment with gabazine $(5 \mu \mathrm{M})$ were examined. The immediate responses of GnRH neurons were abolished completely by the $\mathrm{GABA}_{\mathrm{A}}$ receptor antagonist at both $2 \mathrm{~Hz}[0.66 \pm 0.19$ to $-0.08 \pm 0.09 \mathrm{~Hz}$, $n=6$ in 4 mice; Wilcoxon test $(\mathrm{W}=-21), p=0.031]$ and $10 \mathrm{~Hz}$ [ $1.86 \pm 0.70$ to $0.11 \pm 0.15 \mathrm{~Hz}, n=6$ in 5 mice; Wilcoxon test $(\mathrm{W}=-21), p=0.031$; Fig. $5 E]$. In contrast, $\mathrm{GABA}_{\mathrm{A}}$ receptor blockade had no significant effect on the delayed responses observed with $2 \mathrm{~Hz}[0.25 \pm 0.14$ to $0.33 \pm 0.14 \mathrm{~Hz}, n=5$ in 3 mice; Wilcoxon test $(\mathrm{W}=3), p=0.813]$ or $10 \mathrm{~Hz}[0.49 \pm 0.17$ to $0.39 \pm 0.19 \mathrm{~Hz}, n=$ 9 in 5 mice; Wilcoxon test $(\mathrm{W}=-33), p=0.0547$; Fig. $5 F]$.

These observations reveal that stimulation of RP3 $\mathrm{V}^{\mathrm{GABA}}$ axons can evoke an immediate $\mathrm{GABA}_{\mathrm{A}}$ receptor-mediated activation of $\mathrm{GnRH}$ neuron firing and/or a delayed, prolonged stimulation that is independent of $\mathrm{GABA}_{\mathrm{A}}$ receptor activation. 
RP3V ${ }^{\mathrm{KISS}}$ and RP3V ${ }^{\mathrm{GABA}}$ neuron regulation of $\mathrm{LH}$ secretion in vivo Effects of optogenetic activation RP3V $V^{\text {KISS }}$ neurons on LH secretion in vivo

The studies above demonstrate that the 10 $\mathrm{Hz}$ activation of RP3V ${ }^{\mathrm{KISS}}$ neurons exerts potent, long-lasting stimulatory effects on GnRH neuron firing in vitro. To determine the functional relevance of these findings, we examined the effects of RP3V $\mathrm{V}^{\mathrm{KISS}}$ neuron activation on $\mathrm{LH}$ secretion in vivo. Anesthetized, AAVinjected, OVX + E mice were implanted with a $100 \mu \mathrm{m}$-diameter optic fiber (ending just above the RP3V) at 15:00 h on the day of the expected LH surge and optogenetic stimulation coupled with tail-tip serial blood sampling begun 90 min later.

In the first experiment, the effect of continuous $10 \mathrm{~Hz}$ blue light stimulation (473 nm laser, $5 \mathrm{~mW}$ ) for $15 \mathrm{~min}$ on $\mathrm{LH}$ secretion was examined in AAV-injected Kiss1-IRES-Cre ${ }^{+/-}(N=5)$ and AAVinjected Kiss1-IRES-Cre ${ }^{-l-}$ (control, $N=$ 5) mice. In Kiss1-IRES-Cre ${ }^{+/-}$mice, activation of ChR2 was found to evoke a substantial increase in $\mathrm{LH}$ secretion with peak $\mathrm{LH}$ of $6.2 \pm 0.9 \mathrm{ng} / \mathrm{ml}$ (repeatedmeasures ANOVA $F_{(1.5,5.9)}=25.8, p=$ 0.0016; post hoc Dunnett's tests, $p=0.007$, $0.023,0.041$, at $10,15,20 \mathrm{~min}$, respectively) that peaked at the end of the $15 \mathrm{~min}$ stimulation and then slowly declined to reach basal levels by $80 \mathrm{~min}$ (Fig. 6A). The identical treatment to AAV-injected, Crenegative littermate controls resulted in no changes in LH secretion (Fig. 6A). We next examined the effect of a longer 30 min period of RP3V $\mathrm{V}^{\mathrm{KISS}}$ neuron stimulation and also compared the effects of continuous and bursting patterns of RP3 $\mathrm{V}^{\mathrm{KISS}}$ neuron stimulation. Continuous $10 \mathrm{~Hz}$ activation for $30 \mathrm{~min}$ (18,000 pulses) evoked a large increase in LH secretion that continued to rise to peak levels of $7.0 \pm 0.7 \mathrm{ng} / \mathrm{ml} \mathrm{LH}$ (repeated-measures ANOVA $F_{(2.3,9.1)}=28.3, p<0.0001$; post hoc Dunnett's tests $p=0.002,0.010$, $0.003,0.002,0.001,0.001,0.005,0.008$ at $10,15,20,25,30,35,50$, and $65 \mathrm{~min}$, respectively) by the end of the period of illumination, with a slow return toward basal levels for the duration of the experiment (Fig. 6B). The bursting pattern of activation for $30 \mathrm{~min}(10 \mathrm{~Hz}, 6 \mathrm{~s}$ on $6 \mathrm{~s}$ off; 9000 pulses total) generated peak LH levels of $9.0 \pm 0.9 \mathrm{ng} / \mathrm{ml}$ LH (repeated-measures ANOVA $F_{(1.5,4.4)}=9.22, p=0.029$; post hoc Dunnett's tests $p=0.042,0.024,0.019$ at 25,30 , and $35 \mathrm{~min}$, respectively) followed by a similar slow decline (Fig. $6 B)$. The profiles of $\mathrm{LH}$ secretion generated by continuous and bursting patterns of RP3 $\mathrm{V}^{\mathrm{KISS}}$ neuron activation were not significantly different (two-way repeated-measures ANOVA $F_{(8,56)}=$ 1.09, $p=0.384$; Fig. $6 B$ ). Similarly, the total LH released above
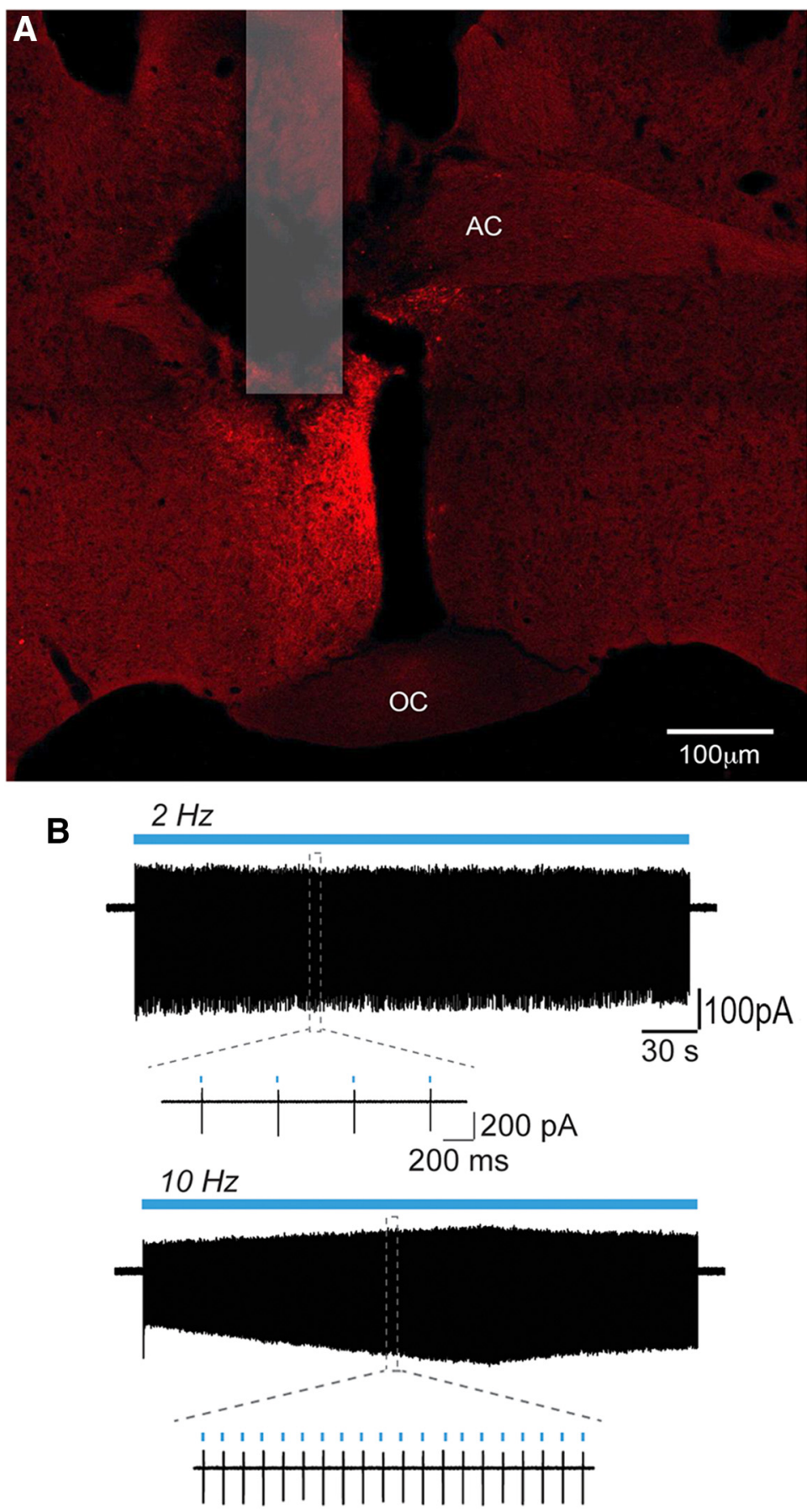

Figure 4. ChR2-mCherry control of RP3V ${ }^{G A B A}$ neuron firing. $A$, Photomicrograph showing location of fiber optic and expression of mCherry following unilateral injection of AAV-ChR2-mCherry into the RP3V of a Vgat-Cre mouse. AC, Anterior commissure; OC, optic chiasm. $B$, Example traces illustrating the response of an RP3V ${ }^{\mathrm{GABA}}$ neuron to 5 min continuous stimulation trains at $2 \mathrm{~Hz}$ (top trace) and at $10 \mathrm{~Hz}$ (bottom trace). Insets show individual spikes at expanded timescales.

baseline, measured as area under the curve, was not significantly different between the continuous $(37 \pm 2 \mathrm{ng} / \mathrm{ml})$ and bursting $(51 \pm 9 \mathrm{ng} / \mathrm{ml})$ patterns of RP3 ${ }^{\mathrm{KISS}}$ neuron activation (MannWhitney test, $p=0.286$ ).

Effects of optogenetic activation $R P 3 V^{G A B A}$ neurons on $L H$ secretion in vivo

Anesthetized, AAV-injected, OVX +E Vgat-Cre mice were treated in the same manner as Kiss1-IRES-Cre mice above. The effects on LH 
A $2 \mathrm{~Hz}$ immediate

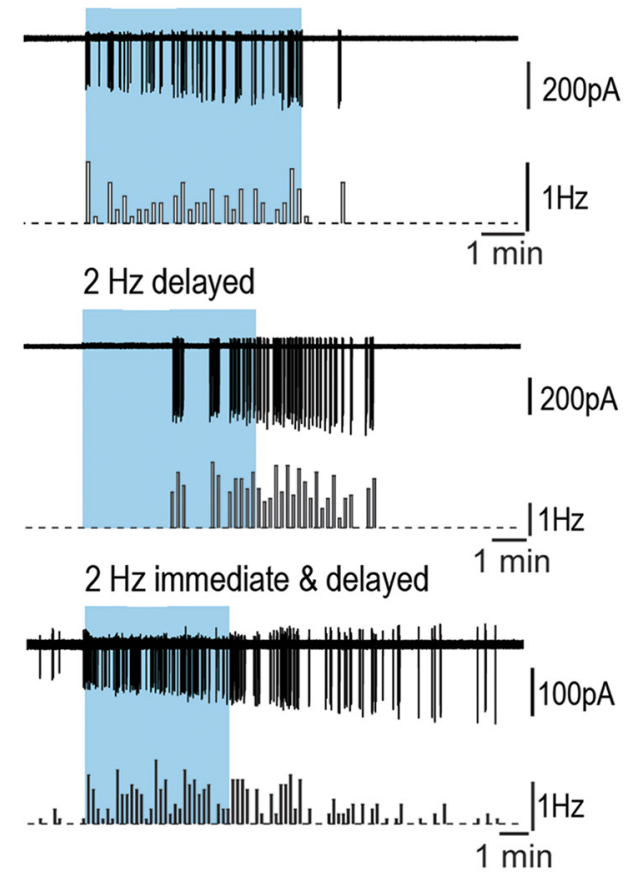

B $\quad 10 \mathrm{~Hz}$ immediate
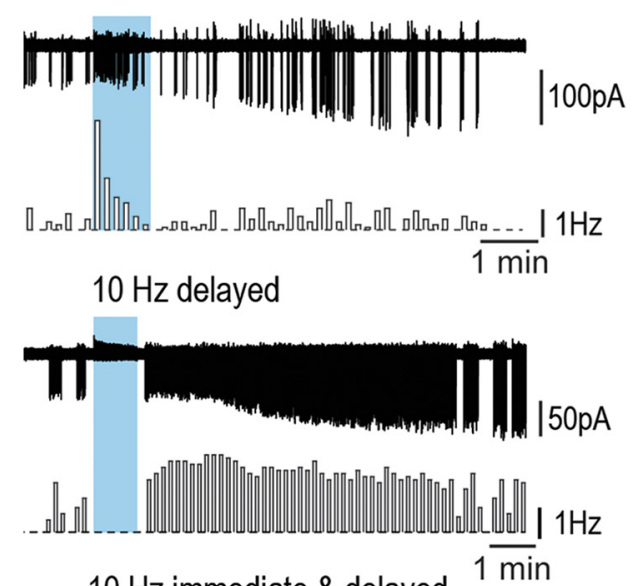

$10 \mathrm{~Hz}$ immediate \& delayed

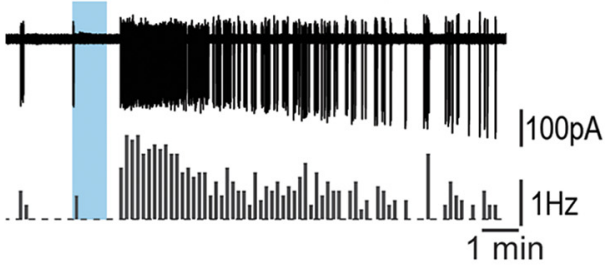

D Delayed response
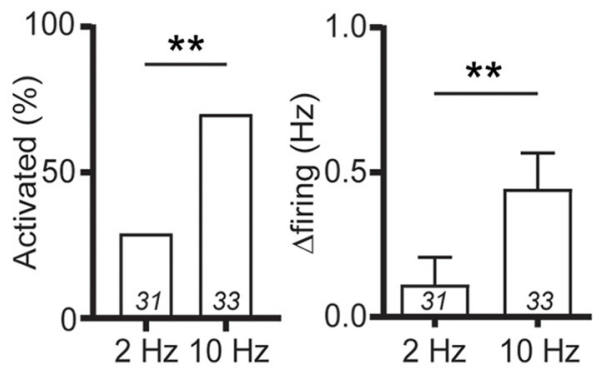

$\mathbf{F}$

Delayed response

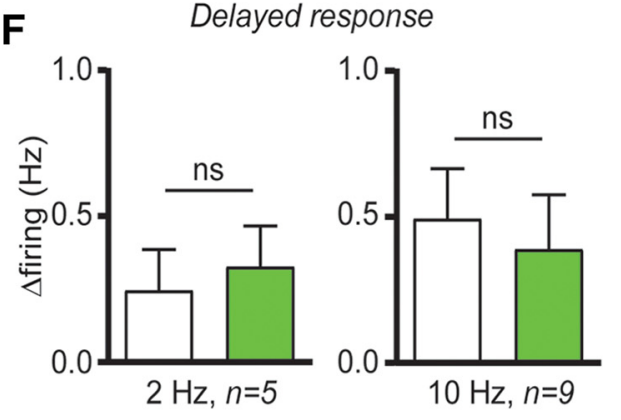

Figure 5. Optogenetic activation of RP3V ${ }^{\text {GABA }}$ neuron axons excites $\mathrm{GnRH}$ neurons. $\boldsymbol{A}, \boldsymbol{B}$, Example traces and corresponding rate meters below (10 $\mathrm{s}$ bins) illustrating the effects of blue-light stimulation trains (300 pulses) on GnRH neuron firing. GnRH neurons increased their action potential firing during the stimulation train (immediate), after the stimulation train (delayed) or both (immediate and delayed) in response to $2 \mathrm{~Hz}(\boldsymbol{A})$ or $10 \mathrm{~Hz}(\boldsymbol{B})$ stimuli. $\boldsymbol{C}$, The immediate response to the stimulation train was seen in similar proportions of $\mathrm{GnRH}$ neurons, but was of larger magnitude at $10 \mathrm{~Hz}$ ( ${ }^{*} p<0.05$; number of cells at base of histograms). $\boldsymbol{D}$, The delayed response to the stimulation train was evoked in a larger proportion of $\mathrm{GnRH}$ neurons and had a larger magnitude at 10 $\mathrm{Hz}$ compared with $2 \mathrm{~Hz}\left({ }^{* *} p<0.01\right)$. $\boldsymbol{E}$, The immediate response at both 2 and $10 \mathrm{~Hz}$ was abolished by $5 \mu \mathrm{m}$ gabazine $\left({ }^{*} p<0.05\right)$, whereas the delayed response $(\boldsymbol{F})$ was not altered.

secretion of continuous $2 \mathrm{~Hz}$ and $10 \mathrm{~Hz}$ stimulation for $15 \mathrm{~min}(5 \mathrm{~ms}$ pulses, $473 \mathrm{~nm}$ laser at $5 \mathrm{~mW}$ ) on LH levels was examined. Activation at $2 \mathrm{~Hz}$ was found to generate a small delayed rise in $\mathrm{LH}$ secretion but this was not significantly greater than baseline $(N=$ 8 , repeated-measures ANOVA $\left.F_{(1.7,11.6)}=2.0, p=0.184\right)$ or different to controls $\left(N=4\right.$, repeated-measures ANOVA $F_{(2.0,6.0)}=$ $0.48, p=0.641$; Fig. $6 C$ ). Controls were mice with either no AAV transfection or misplaced optic fibers above or lateral to the $\mathrm{RP} 3 \mathrm{~V}$. Activation at $10 \mathrm{~Hz}$ evoked a potent increase in $\mathrm{LH}$ secre- tion reaching $5.0 \pm 0.7 \mathrm{ng} / \mathrm{ml}$ by the end of the blue light stimulation $\left(N=7\right.$, repeated-measures ANOVA $F_{(2.3,13.7)}=21.6, p<$ 0.001 , post hoc Dunnett's tests $p=0.049,0.008,0.005$, and 0.009 at $10,15,20$, and $35 \mathrm{~min}$, respectively) with levels declining toward baseline by $60 \mathrm{~min}$ (Fig. 6D). Control mice with no ChR2 transfection or misplaced optic fibers exhibited no change in $\mathrm{LH}$ secretion during $10 \mathrm{~Hz}$ blue light illumination for $15 \min \left(N=6\right.$, repeated-measures $\operatorname{ANOVA~} F_{(2.7,13.5)}=$ 2.98, $p=0.073$; Fig. $6 D)$. 

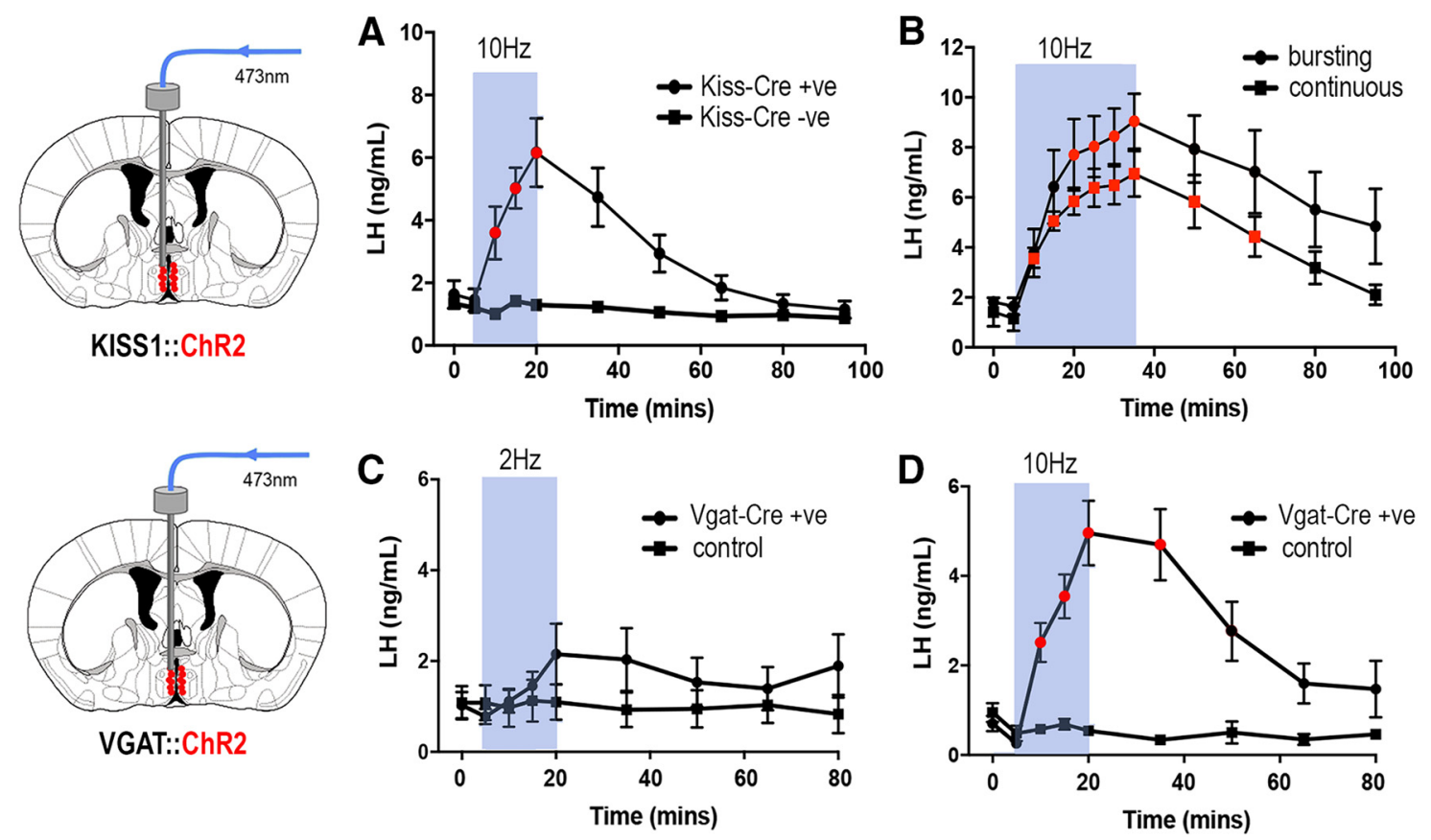

Figure 6. Effects on LH secretion of optogenetic activation of RP $3 V^{\text {KISS }}$ and RP3V ${ }^{G A B A}$ neurons in vivo. A, Activation of RP $3 V^{\text {KISS }}$ neurons at $10 \mathrm{~Hz}$ for 15 min increases $\mathrm{LH}$ secretion in $A A V$-injected Kiss7-IRES-Cre mice $(n=5)$ but not wild-type controls $(n=5)$. Symbols in red show time points significantly different to prestimulation values (repeated-measures ANOVA with post hoc Dunnett's; see results for exact $p$ values). $\boldsymbol{B}$, Activation of RP3V ${ }^{\mathrm{KISS}}$ neurons at $10 \mathrm{~Hz}$ for 30 min using either a bursting $(n=4)$ or continuous $(n=5)$ stimulation pattern significantly increases $\mathrm{LH}$ secretion in AAV-injected Kiss7-IRES-Cre mice. C, Activation of RP3V GABA neurons at $2 \mathrm{~Hz}$ for 15 min has no significant effect on LH secretion in AAV-injected Vgat-Cre mice $(n=8)$ or controls $(n=4)$. $D$, Activation of RP3V GABA neurons at $10 \mathrm{~Hz}$ for 15 min significantly increases $\mathrm{LH}$ secretion in AAV-injected Vgat-Cre mice $(n=7)$ but not controls $(n=6)$. Symbols in red show time points significantly different to prestimulation values (repeated-measures ANOVA with post hoc Dunnett's tests; see results for exact $p$ values).

\section{Relative contributions of RP3V GABA-kisspeptin signaling in regulating $\mathrm{GnRH}$ neuron firing}

The above data demonstrate that the $10 \mathrm{~Hz}$ stimulation of RP3V $\mathrm{V}^{\mathrm{KISS}}$ and $\mathrm{RP} 3 \mathrm{~V}^{\mathrm{GABA}}$ neurons is a powerful activator of $\mathrm{GnRH}$ neuron firing resulting in potent and long-lasting effects on $\mathrm{LH}$ secretion. Direct comparisons between the effects of $10 \mathrm{~Hz}$ activation of $\mathrm{RP} 3 \mathrm{~V}^{\mathrm{KISS}}$ and $\mathrm{RP} 3 \mathrm{~V}^{\mathrm{GABA}}$ neurons on $\mathrm{GnRH}$ neuron firing in vitro (Fig. $7 A$ ) and on $\mathrm{LH}$ secretion in vivo (Fig. $7 B$ ) revealed very similar electrical and secretion response profiles. As $20-75 \%$ of RP3V ${ }^{\text {KISS }}$ neurons are GABAergic (Cravo et al., 2011; Cheong et al., 2015), it was likely that $10 \mathrm{~Hz}$ optogenetic stimulation in these two animal models was activating the same population of RP3V neurons using GABA-kisspeptin cotransmission.

To explore this, we first established the degree to which $\mathrm{GABA}_{\mathrm{A}}$ receptor signaling was contributing to $\mathrm{GnRH}$ neuron responses following optogenetic activation of RP3V ${ }^{\text {KISS }}$ neurons in AAVinjected, Kiss1-IRES-Cre;GnRH-GFP mice. A brain slice protocol was established in which two 1 min stimuli $(10 \mathrm{~Hz})$ separated by 15 min generated identical GnRH neuron responses (Fig. 7C). We then tested the role of $\mathrm{GABA}_{\mathrm{A}}$ transmission by including $5 \mu \mathrm{M}$ gabazine over the time of the second stimulus (S2). The presence of gabazine during S2 resulted in a marked reduction in the immediate GnRH neuron response $(0.65 \pm 0.23$ to $-0.07 \pm 0.07 \mathrm{~Hz}, p=0.009$, two-way ANOVA with Bonferroni post-test; Fig. 7D), whereas the delayed GnRH neuron response was unaffected $(0.52 \pm 0.07$ to $0.42 \pm 0.08 \mathrm{~Hz}, p=0.999$, two-way ANOVA with Bonferroni posttest; $n=10$ in 5 mice; Fig. $7 C-E$ ).

This indicated that, as in experiments stimulating RP3V $\mathrm{V}^{\mathrm{GABA}}$ neurons, GABA release contributed to immediate GnRH neuron responses to $\mathrm{RP} 3 \mathrm{~V}^{\mathrm{KISS}}$ neurons activation. To verify this, we reassessed the responses of individual $\mathrm{GnRH}$ neurons to optogenetic $\mathrm{RP} \mathrm{V}^{\mathrm{KISS}}$ neuron activation and found that 9 of 69 responding
GnRH neurons (13\%) exhibited the immediate activation profile (Fig. $7 G$ ). In the next experiment, we identified four such $\mathrm{GnRH}$ neurons exhibiting this immediate response in Kiss1-IRES-Cre; GnRH-GFP mice $(N=4)$, and tested the effects of gabazine (Fig. $7 F$ ). This was again found to abolish the immediate activation evoked by $10 \mathrm{~Hz}$ blue-light stimulation (change in firing $0.79 \pm$ 0.23 to $-0.17 \pm 0.17 \mathrm{~Hz}$, one-way paired $t$ test, $p=0.042$ ) while having no effect on the delayed response (Fig. $7 H$ ).

In the absence of effective kisspeptin receptor antagonists (Albers-Wolthers et al., 2017), the contribution of kisspeptin to GnRH neuron responses after RP3V $\mathrm{VABA}^{\mathrm{GAB}}$ neuron activation is difficult to establish. Nevertheless, using dual immunofluorescence we were able to demonstrate that $21 \pm 8 \%$ of $\mathrm{RP} 3 \mathrm{~V}$ kisspeptin neurons expressed mCherry/ChR2 in AAVinjected, OVX+E Vgat-Cre mice $(N=5)$. Thus, as in Kiss1IRES-Cre animals, optogenetic stimulation in Vgat-Cre mice would be expected to activate a population of GABAkisspeptin neurons that project to GnRH neurons.

To evaluate the functional importance of the neuropeptide kisspeptin in RP3V neurons, we returned to the in vivo optogenetic approach but took advantage of a different kisspeptin-Cre mouse line in which homozygous mice have Kiss1 deleted from all Cre-expressing kisspeptin neurons (Yeo et al., 2016). Anesthetized, AAV-ChR2-injected, Kiss1-Cre ${ }^{+/+} \mathrm{OVX}+\mathrm{E}$ mice of this line were given the blood sample collection and $15 \mathrm{~min}$ RP3V blue light illumination protocol as in the prior experiments. This was found to have no effect on LH secretion (repeated-measures ANOVA $F_{(1.4,2.7)}=4.95, p=0.124$; Fig. $\left.7 B\right)$.

\section{Discussion}

We report here that the RP3V provides two parallel input streams to $\mathrm{GnRH}$ neurons represented by a fast, low-frequency activated 
A

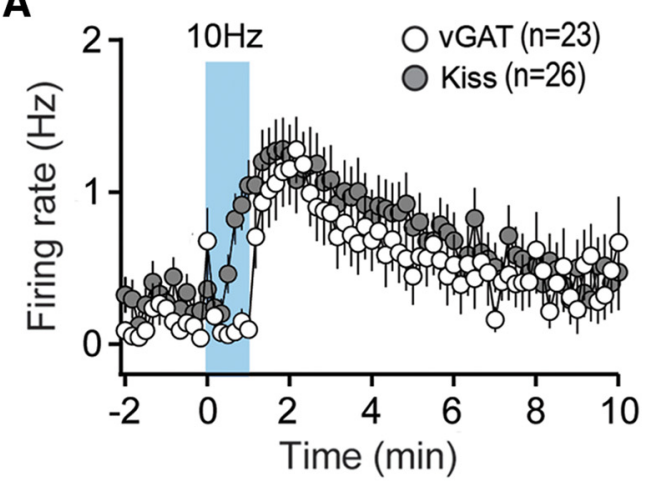

C

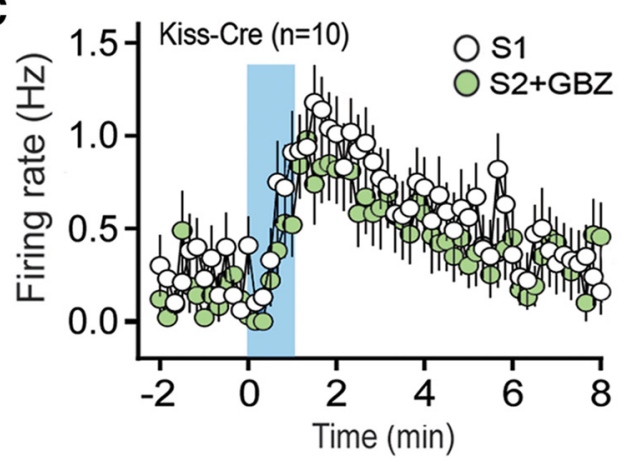

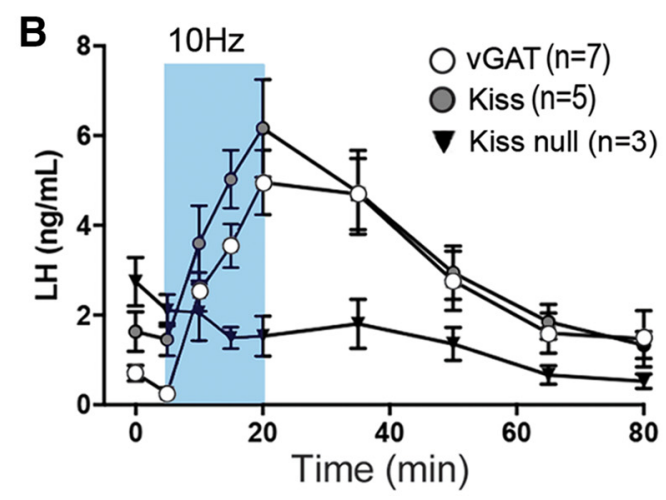

D

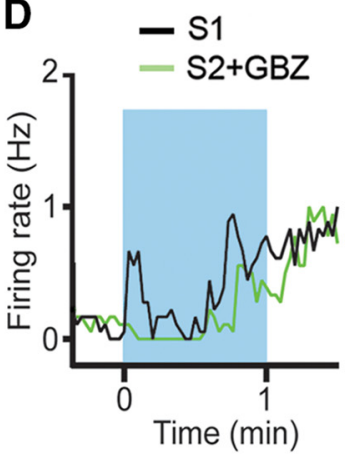

E

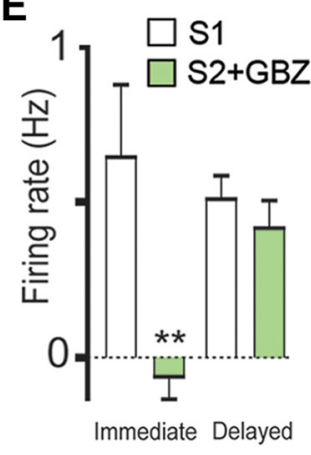

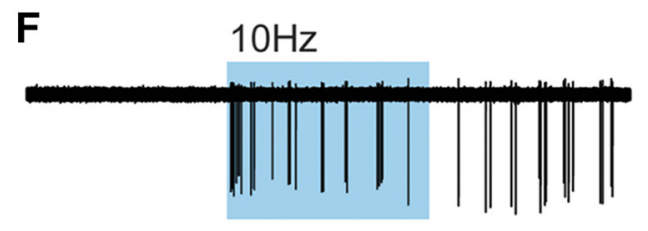
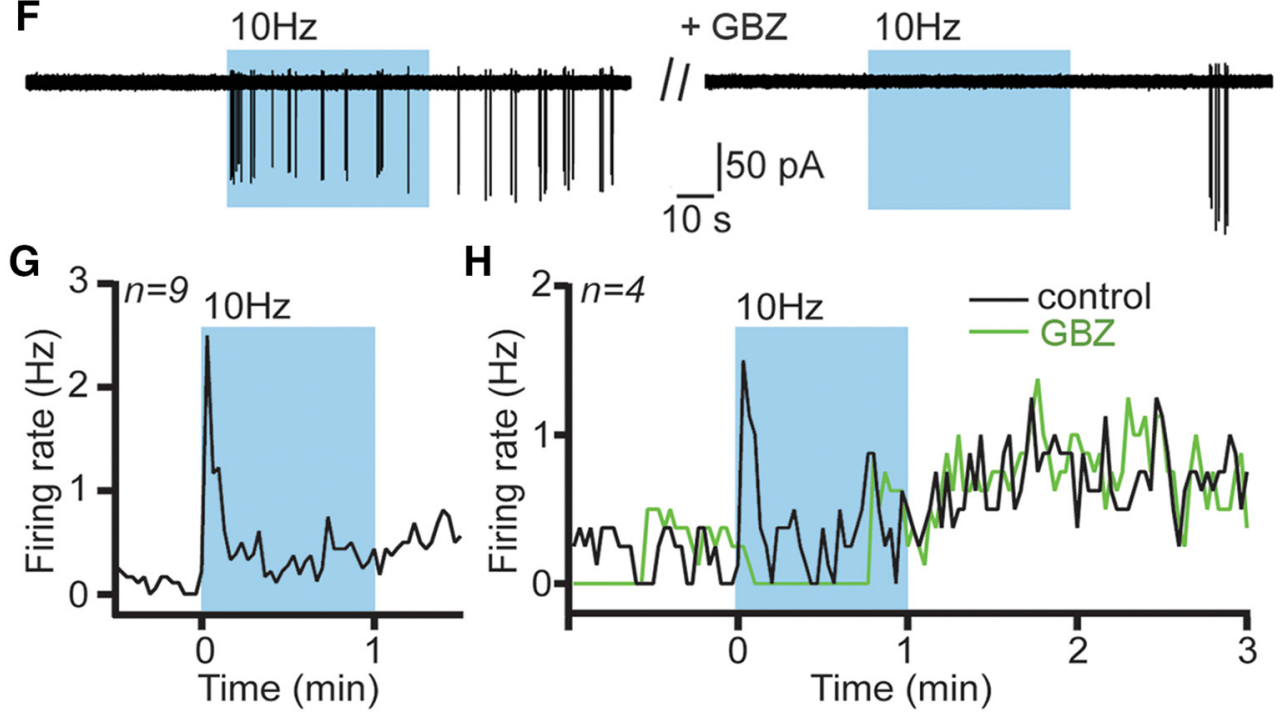

Figure 7. GABA-kisspeptin cotransmission in the regulation of $\mathrm{GnRH}$ neuron firing and $L$ H secretion. $A$, Superimposition of $G \mathrm{nRH}$ neuron firing responses to optogenetic activation (600 pulses at $10 \mathrm{~Hz}$ ) of RP3V ${ }^{\text {GABA }}$ neuron (white circles) or RP3V KISS neuron (gray circles) axons. B, Time course of LH secretion in response to 15 min, $10 \mathrm{~Hz}$ optogenetic activation of RP3V GABA neurons (from Fig. 5D), RP3V KISS neurons (from Fig. 5A), and RP3V KISS neurons in which kisspeptin has been deleted (kiss-null). C, Two successive optogenetic activations (600 pulses at $10 \mathrm{~Hz}$ ) of RP3V KISS neuron axons were delivered at $15 \mathrm{~min}$ intervals, with the second stimulus delivered in the presence of gabazine $(G B Z ; 5 \mu \mathrm{m})$ in the bath. $D$, Expanded view of the 1 min optogenetic stimulation period showing the suppression of immediate mean $\mathrm{GnRH}$ neuron firing by GBZ (green trace). $\boldsymbol{E}$, The immediate response was abolished by GBZ, whereas the delayed response was unaffected ( ${ }^{* *} p<0.01$ ). $\boldsymbol{F}$, The immediate response of a $\mathrm{GnRH}$ neuron to a blue-light stimulation train ( 600 pulses at $10 \mathrm{~Hz}$ ) is abolished in the presence of $\mathrm{GBZ}$. $G$, Time course showing the mean firing rates of $9 \mathrm{GnRH}$ neurons that exhibited immediate responses to blue-light stimulation in AAV-injected Kiss 1 -IRES-Cre mice. $\boldsymbol{H}$, In a further four GnRH neurons displaying this immediate response following $10 \mathrm{~Hz}$ blue light stimulation of RP3V KISS neuron axons (black line), treatment with GBZ (green line) abolished the immediate increase in firing but had no effect on the delayed increase observed after the stimulation.

GABAergic pathway and a slower onset, high-frequency stimulated kisspeptin signal (Fig. 8). Although these input streams can occur within individual RP3V neurons coexpressing GABA and kisspeptin, it is evident that some RP3V neurons express only GABA or kisspeptin. In considering the functional implications of these $\mathrm{RP} 3 \mathrm{~V}$ inputs we first discuss kisspeptin and GABA as individual components before addressing cotransmission.
RP3V KIss neuron control of GnRH neurons and $\mathrm{LH}$ secretion The selective optogenetic activation of RP $3 V^{\text {KISS }}$ neurons was found to trigger a delayed but powerful stimulation of firing in $\sim 70 \%$ of GnRH neurons. This is in good agreement with evidence that RP3V ${ }^{\text {KISS }}$ neurons project to GnRH neurons (Kumar et al., 2015; Yip et al., 2015) that express the kisspeptin receptor in a selective manner within the rPOA (Herbison et al., 2010), and 
that exogenous kisspeptin generates a similar delayed but potent activation of $\sim 80 \%$ of $\mathrm{GnRH}$ neurons (Piet et al., 2015b). We find that RP3V ${ }^{\mathrm{KISS}}$ neurons need to be activated at $5-10 \mathrm{~Hz}$ for at least 30 s to activate spiking in GnRH neurons. A prior study has reported that 20 $\mathrm{Hz}$ optogenetic stimulation at $30 \mathrm{~s}$ depolarizes GnRH neurons in vitro (Qiu et al., 2016). The $10 \mathrm{~Hz}$ threshold for kisspeptin neuron activation is compatible with the prevailing concept that neuropeptide secretion requires high-frequency stimulation of the nerve terminal (Lundberg and Hokfelt, 1983; Verhage et al., 1991; Leng and Ludwig, 2008; Schöne and Burdakov, 2012).

The selective activation of RP3V KISS neurons also resulted in a robust increase in $\mathrm{LH}$ secretion in vivo. This observation provides critical support for the hypothesis that RP3 ${ }^{\mathrm{KISS}}$ neurons underlie the generation of the GnRH/LH surge (Clarkson and Herbison, 2009; Oakley et al., 2009; Roa et al., 2009; Khan and Kauffman, 2012; Herbison, 2016). We find that activating $\mathrm{RP}^{\mathrm{K}} \mathrm{KISS}$ neurons for 15 min generates a $1 \mathrm{~h}$ long, $\sim 6 \mathrm{ng} / \mathrm{ml}$ rise in $\mathrm{LH}$, whereas activation for 30 min evokes a 90 -min-duration increase in $\mathrm{LH}$ with peak levels of $\sim 8 \mathrm{ng} / \mathrm{ml}$. Whereas the amplitude of the rise in $\mathrm{LH}$ is the same as the endogenous $\mathrm{LH}$ surge in OVX $+\mathrm{E}$ mice $(\sim 8$ $\mathrm{ng} / \mathrm{ml} \mathrm{LH}$ ), the profile of $\mathrm{LH}$ secretion is different with optogenetics generating a rapid 15-30 min increase to peak compared with the normal gradual rise over $\sim 90 \mathrm{~min}$ (Czieselsky et al., 2016). As also indicated by cFOS studies in GnRH and kisspeptin neurons (Lee et al., 1992; Poling et al., 2017), this suggests that a more gradual pattern of increased RP $3 \mathrm{~V}^{\mathrm{KISS}}$ neuron firing occurs on the afternoon of the surge.

We also examined here the impact of evoking a bursting pattern of kisspeptin input to the GnRH neurons. While this generated a profile of GnRH neuron activation equivalent to that of the continuous stimulation, it was intriguing to note that this was much more efficient at generating LH secretion in vivo with 9000 burst pulses having same magnitude effect as 18,000 continuous pulses. This suggests that the bursting activation of $\mathrm{GnRH}$ neurons, and presumably episodic release of GnRH into the pituitary portal system, may be a more efficient stimulation profile for the pituitary gland at the time of the surge. Interestingly, this was not found to be the case for the pulsatile mode of LH secretion (Campos and Herbison, 2014).

\section{RP3V ${ }^{\text {GABA }}$ neuron control of GnRH neurons and}

\section{LH secretion}

A previous study using low-frequency electrical activation of all neurons in the RP3V identified the presence of GABAergic inputs from this area to GnRH neurons (Liu et al., 2011). This is confirmed here using more selective optogenetic activation of RP3V ${ }^{\mathrm{GABA}}$ neurons. Although we were unable to establish immunohistochemically that ChR2 was expressed only in GABA neurons in the RP3V, we note that the Vgat-Cre line used here targets GABAergic neurons selectively throughout the brain (Vong et al., 2011) and that the immediate effects of optogenetic RP3 $\mathrm{V}^{\mathrm{GABA}}$ neuron activation were abolished completely by a $\mathrm{GABA}_{\mathrm{A}}$ receptor antagonist.
The activation of RP3 $\mathrm{V}^{\mathrm{GABA}}$ neurons in the brain slice generated an immediate $\mathrm{GABA}_{\mathrm{A}}$ receptor-mediated increase in firing in $\sim 50 \%$ of GnRH neurons. This confirms the excitatory nature of $\mathrm{GABA}_{\mathrm{A}}$ receptor activation by endogenous $\mathrm{GABA}$ release in adult GnRH neurons (Herbison and Moenter, 2011). In many cases, we note that the increase in $\mathrm{GnRH}$ firing did not persist for the duration of optogenetic stimulation. This may be due to the fatigue of the releasable pool of GABA from RP3V ${ }^{\mathrm{GABA}}$ neuron terminals or a variety of postsynaptic changes in the GnRH neuron.

Low-frequency $2 \mathrm{~Hz}$ activation of the RP3V $\mathrm{VABA}^{\mathrm{GA}} \rightarrow \mathrm{GnH}$ neuron input generated modest $(<0.3 \mathrm{~Hz})$ changes in $\mathrm{GnRH}$ neuron firing but no significant effects on $\mathrm{LH}$ secretion in vivo. Although even single action potentials generate elevated calcium concentrations in GnRH nerve terminals (Iremonger et al., 2017), this indicates that small $\mathrm{GABA}_{\mathrm{A}}$ receptor-mediated increases in $\mathrm{GnRH}$ neuron firing have little impact on pituitary $\mathrm{LH}$ secretion at the time of the LH surge. Notably, a selective $90 \%$ deletion of $\mathrm{GABA}_{\mathrm{A}}$ receptor signaling at the $\mathrm{GnRH}$ neuron was previously found to have no effect on the LH surge (Lee et al., 2010) and a recent study using a realistic model of the $\mathrm{LH}$ surge reported that GnRH neuron $\mathrm{GABA}_{\mathrm{A}}$ receptor dynamics do not change at this time (Liu et al., 2017). Nevertheless, the acute administration of $\mathrm{GABA}_{\mathrm{A}}$ receptor antagonists into the rPOA effectively blocks the LH surge in rats (Herbison and Dyer, 1991). Thus, although a fast stimulatory $\mathrm{RP} 3 \mathrm{~V}^{\mathrm{GABA}} \rightarrow \mathrm{GnRH}$ neuron pathway clearly exists, its functional impact on gonadotropin secretion remains unclear. It is also important to consider that the RP3 $\mathrm{V}^{\mathrm{GABA}}$ input is only one of several GABAergic pathways impinging on the GnRH neuron cell body (Christian and Moenter, 2007; Penatti et al., 2010; Moore et al., 2015).

\section{GABA-kisspeptin cotransmission}

Evidence presented here suggests that the activation of RP3V $\mathrm{V}^{\mathrm{KISS} / \mathrm{GABA}}$ neurons for $>30 \mathrm{~s}$ and $\sim 10 \mathrm{~Hz}$ will be encoded into two parallel frequency-dependent and temporally differentiated spike outputs to 
GnRH neurons (Fig. 8). In one stream, GABA acts as a rapid, temporally precise signal while the other provides a delayed but potent, long-lasting stimulus to $\mathrm{GnRH}$ neurons. This latter action is almost certainly mediated by kisspeptin; it is identical in profile between Kiss1-IRES-Cre and Vgat-Cre mice, the same as that observed with exogenous kisspeptin (Piet et al., 2015b), and the effects on LH secretion are ablated completely with selective deletion of kisspeptin from kisspeptin neurons. This effect of kisspeptin is compatible with current concepts of slow neuropeptide transmission being used when long-lasting effects are required (Leng and Ludwig, 2008; Schöne and Burdakov, 2012); in this case, the activation of $\mathrm{GnRH}$ neurons for hours to generate the GnRH/LH surge (Smith et al., 2006; Herbison, 2016).

The role of the temporally precise GABA signal in RP3V cotransmission is less clear. The GABA release itself is shown here to not have any direct impact upon $\mathrm{LH}$ secretion and unlike the situation with other neurons coexpressing GABA (Tritsch et al., 2016), does not seem to interact with its cotransmitter kisspeptin. Blockade of $\mathrm{GABA}_{\mathrm{A}}$ receptor signaling in vitro was not found to affect the subsequent delayed activation of GnRH neurons. It is possible that conventional, fast GABA signaling represents the "basal" mode of RP3V $\mathrm{VISS}^{\mathrm{GABA}} \rightarrow \mathrm{GnRH}$ neuron communication active throughout the estrous cycle, with kisspeptin transmission only becoming active on the day of the LH surge when subpopulations of RP3V $\mathrm{V}^{\mathrm{KISS}}$ neurons are able to transcend to $>10 \mathrm{~Hz}$ firing rates (Fig. 8). At present, the firing rates of RP3V ${ }^{\text {KISS }}$ neurons across the estrous cycle or at time of the $\mathrm{LH}$ surge remain unknown in vivo.

We note that only $\sim 40 \%$ of GnRH neurons were demonstrated to receive $\mathrm{RP} 3 \mathrm{~V}$ inputs exhibiting functional GABA-kisspeptin cotransmission. This is not unexpected given that GABA and kisspeptin are coexpressed in subpopulations of RP3V kisspeptin and GABA neurons (Cravo et al., 2011; Cheong et al., 2015) and, at this stage, it is unclear which subpopulations of $\mathrm{GnRH}$ neurons are innervated by which RP3V ${ }^{\text {KISS/GABA }}$ neurons (Kumar et al., 2015; Herbison, 2016). Interestingly, it was recently reported that $\mathrm{RP} 3 \mathrm{~V}^{\mathrm{KISS}}$ neurons innervating GnRH neurons were enriched in tyrosine hydroxylase (TH; Kumar et al., 2015), suggesting that dopamine may be another coexpressed transmitter in these cells. However, activation of the RP3V as a whole failed to generate dopamine receptor-mediated responses in GnRH neurons (Liu and Herbison, 2013) and the selective deletion of TH from kisspeptin neurons was recently found to have no impact on $\mathrm{GnRH}$ neurons or fertility (Stephens et al., 2017). It is possible that, as in some other neural populations (Xenias et al., 2015), TH does not synthesize dopamine in RP3 $\mathrm{V}^{\mathrm{KISS}}$ neurons.

In summary, we demonstrate that the selective optogenetic activation of RP3 $\mathrm{V}^{\mathrm{KISS}}$ neurons provides a potent stimulus to $\mathrm{GnRH}$ neuron firing and $\mathrm{LH}$ secretion at the time of the LH surge. For many GnRH neurons, sustained activation of RP3V neuronal inputs results in the generation of two parallel modes of synaptic transmission; a rapid and transient $\mathrm{GABA}_{\mathrm{A}}$ receptor-mediated activation and a slower onset kisspeptin-mediated stimulation of long duration. During such times of sustained activation, the release of GABA becomes functionally redundant as the neuropeptide kisspeptin represents the dominant cotransmitter regulating output of the $\mathrm{GnRH}$ neuron and $\mathrm{LH}$ secretion.

\section{References}

Albers-Wolthers CHJ, de Gier J, Walen M, van Kooten PJS, Lambalk CB, Leegwater PAJ, Roelen BAJ, Schaefers-Okkens AC, Rutten VPMG, Millar RPM, Kooistra HS (2017) In vitro and in vivo effects of kisspeptin antagonists p234, p271, p354, and p356 on GPR54 activation. PLoS One 12: e0179156. CrossRef Medline
Atasoy D, Betley JN, Su HH, Sternson SM (2012) Deconstruction of a neural circuit for hunger. Nature 488:172-177. CrossRef Medline

Bronson FH, Vom Saal FS (1979) Control of the preovulatory release of luteinizing hormone by steroids in the mouse. Endocrinology 104:12471255. CrossRef Medline

Burnstock G (2004) Cotransmission. Curr Opin Pharmacol 4:47-52. CrossRef Medline

Campbell JN, Macosko EZ, Fenselau H, Pers TH, Lyubetskaya A, Tenen D, Goldman M, Verstegen AM, Resch JM, McCarroll SA, Rosen ED, Lowell BB, Tsai LT (2017) A molecular census of arcuate hypothalamus and median eminence cell types. Nat Neurosci 20:484-496. CrossRef Medline

Campos P, Herbison AE (2014) Optogenetic activation of GnRH neurons reveals minimal requirements for pulsatile luteinizing hormone secretion. Proc Natl Acad Sci U S A 111:18387-18392. CrossRef Medline

Chen R, Wu X, Jiang L, Zhang Y (2017) Single-cell RNA-seq reveals hypothalamic cell diversity. Cell reports 18:3227-3241. CrossRef Medline

Cheong RY, Czieselsky K, Porteous R, Herbison AE (2015) Expression of ESR1 in glutamatergic and GABAergic neurons is essential for normal puberty onset, estrogen feedback, and fertility in female mice. J Neurosci 35:14533-14543. CrossRef Medline

Christian CA, Moenter SM (2007) Estradiol induces diurnal shifts in GABA transmission to gonadotropin-releasing hormone neurons to provide a neural signal for ovulation. J Neurosci 27:1913-1921. CrossRef Medline

Clarkson J, Herbison AE (2009) Oestrogen, kisspeptin, GPR54 and the pre-ovulatory luteinising hormone surge. J Neuroendocrinol 21:305-311. CrossRef Medline

Clarkson J, Herbison AE (2011) Dual phenotype kisspeptin-dopamine neurones of the rostral periventricular area of the third ventricle project to gonadotrophin-releasing hormone neurones. J Neuroendocrinol 23:293301. CrossRef Medline

Clarkson J, d'Anglemont de Tassigny X, Moreno AS, Colledge WH, Herbison AE (2008) Kisspeptin-GPR54 signaling is essential for preovulatory gonadotropin-releasing hormone neuron activation and the luteinizing hormone surge. J Neurosci 28:8691-8697. CrossRef Medline

Clarkson J, Boon WC, Simpson ER, Herbison AE (2009a) Postnatal development of an estradiol-kisspeptin positive feedback mechanism implicated in puberty onset. Endocrinology 150:3214-3220. CrossRef Medline

Clarkson J, d'Anglemont de Tassigny X, Colledge WH, Caraty A, Herbison AE (2009b) Distribution of kisspeptin neurones in the adult female mouse brain. J Neuroendocrinol 21:673-682. CrossRef Medline

Cravo RM, Margatho LO, Osborne-Lawrence S, Donato J Jr, Atkin S, Bookout AL, Rovinsky S, Frazão R, Lee CE, Gautron L, Zigman JM, Elias CF (2011) Characterization of Kiss1 neurons using transgenic mouse models. Neuroscience 173:37-56. CrossRef Medline

Czieselsky K, Prescott M, Porteous R, Campos P, Clarkson J, Steyn FJ, Campbell RE, Herbison AE (2016) Pulse and surge profiles of luteinizing hormone secretion in the mouse. Endocrinology 157:4794-4802. CrossRef Medline

de Croft S, Piet R, Mayer C, Mai O, Boehm U, Herbison AE (2012) Spontaneous kisspeptin neuron firing in the adult mouse reveals marked sex and brain region differences but no support for a direct role in negative feedback. Endocrinology 153:5384-5393. CrossRef Medline

Herbison AE (2015) Physiology of the adult GnRH neuronal network. In: Knobil and Neill's physiology of reproduction, Ed 4 (Plant TM, Zeleznik AJ, eds), pp 399-467. New York: Academic.

Herbison AE (2016) Control of puberty onset and fertility by gonadotropinreleasing hormone neurons. Nat Rev Endocrinol 12:452-466. CrossRef Medline

Herbison AE, Dyer RG (1991) Effect on luteinizing hormone secretion of GABA receptor modulation in the medial preoptic area at the time of proestrous luteinizing hormone surge. Neuroendocrinology 53:317-320. CrossRef Medline

Herbison AE, Moenter SM (2011) Depolarising and hyperpolarising actions of $\mathrm{GABA}(\mathrm{A})$ receptor activation on gonadotrophin-releasing hormone neurones: towards an emerging consensus. J Neuroendocrinol 23:557569. CrossRef Medline

Herbison AE, de Tassigny Xd, Doran J, Colledge WH (2010) Distribution and postnatal development of Gpr54 gene expression in mouse brain and gonadotropin-releasing hormone neurons. Endocrinology 151:312-321. CrossRef Medline

Iremonger KJ, Porteous R, Herbison AE (2017) Spike and neuropeptide- 
dependent mechanisms control GnRH neuron nerve terminal $\mathrm{Ca}^{2+}$ over diverse time scales. J Neurosci 37:3342-3351. CrossRef Medline

Jan YN, Jan LY (1983) A LHRH-like peptidergic neurotransmitter capable of "action at a distance" in autonomic ganglia. Trends Neurosci 6:320325. CrossRef

Khan AR, Kauffman AS (2012) The role of kisspeptin and RFamide-related peptide-3 neurones in the circadian-timed preovulatory luteinising hormone surge. J Neuroendocrinol 24:131-143. CrossRef Medline

Krashes MJ, Shah BP, Koda S, Lowell BB (2013) Rapid versus delayed stimulation of feeding by the endogenously released AgRP neuron mediators GABA, NPY, and AgRP. Cell Metab 18:588-595. CrossRef Medline

Kumar D, Candlish M, Periasamy V, Avcu N, Mayer C, Boehm U (2015) Specialized subpopulations of kisspeptin neurons communicate with GnRH neurons in female mice. Endocrinology 156:32-38. CrossRef Medline

Lee K, Porteous R, Campbell RE, Lüscher B, Herbison AE (2010) Knockdown of $\mathrm{GABA}(\mathrm{A})$ receptor signaling in $\mathrm{GnRH}$ neurons has minimal effects upon fertility. Endocrinology 151:4428-4436. CrossRef Medline

Lee WS, Smith MS, Hoffman GE (1992) cFos activity identifies recruitment of luteinizing hormone-releasing hormone neurons during the ascending phase of the proestrous luteinizing hormone surge. J Neuroendocrinol 4:161-166. CrossRef Medline

Leng G, Ludwig M (2008) Neurotransmitters and peptides: whispered secrets and public announcements. J Physiol 586:5625-5632. CrossRef Medline

Liu X, Herbison AE (2013) Dopamine regulation of gonadotropin-releasing hormone neuron excitability in male and female mice. Endocrinology 154:340-350. CrossRef Medline

Liu X, Porteous R, d'Anglemont de Tassigny X, Colledge WH, Millar R, Petersen SL, Herbison AE (2011) Frequency-dependent recruitment of fast amino acid and slow neuropeptide neurotransmitter release controls gonadotropin-releasing hormone neuron excitability. J Neurosci 31: 2421-2430. CrossRef Medline

Liu X, Porteous R, Herbison AE (2017) Dynamics of GnRH neuron ionotropic GABA and glutamate synaptic receptors are unchanged during estrogen positiveand negativefeedbackinfemalemice.eNeuro4:ENEURO. 0259-17.2017. CrossRef Medline

Lundberg JM, Hokfelt T (1983) Coexistence of peptides and classical neurotransmitters. Trends Neurosci 6:325-333. CrossRef

Mayer C, Acosta-Martinez M, Dubois SL, Wolfe A, Radovick S, Boehm U, Levine JE (2010) Timing and completion of puberty in female mice depend on estrogen receptor $\alpha$-signaling in kisspeptin neurons. Proc Natl Acad Sci USA 107:22693-22698. CrossRef Medline

Moore AM, Prescott M, Marshall CJ, Yip SH, Campbell RE (2015) Enhancement of a robust arcuate GABAergic input to gonadotropin-releasing hormone neurons in a model of polycystic ovarian syndrome. Proc Natl Acad Sci U S A 112:596-601. CrossRef Medline

Oakley AE, Clifton DK, Steiner RA (2009) Kisspeptin signaling in the brain. Endocr Rev 30:713-743. CrossRef Medline

Padilla SL, Qiu J, Soden ME, Sanz E, Nestor CC, Barker FD, Quintana A, Zweifel LS, Rønnekleiv OK, Kelly MJ, Palmiter RD (2016) Agoutirelated peptide neural circuits mediate adaptive behaviors in the starved state. Nat Neurosci 19:734-741. CrossRef Medline

Penatti CA, Davis MC, Porter DM, Henderson LP (2010) Altered GABAA receptor-mediated synaptic transmission disrupts the firing of gonadotropin-releasing hormone neurons in male mice under conditions that mimic steroid abuse. J Neurosci 30:6497-6506. CrossRef Medline

Piet R, Fraissenon A, Boehm U, Herbison AE (2015a) Estrogen permits vasopressin signaling in preoptic kisspeptin neurons in the female mouse. J Neurosci 35:6881-6892. CrossRef Medline

Piet R, de Croft S, Liu X, Herbison AE (2015b) Electrical properties of kisspeptin neurons and their regulation of GnRH neurons. Front Neuroendocrinol 36:15-27. CrossRef Medline

Poling MC, Luo EY, Kauffman AS (2017) Sex differences in steroid receptor coexpression and circadian-timed activation of kisspeptin and RFRP-3 neurons may contribute to the sexually dimorphic basis of the LH surge. Endocrinology 158:3565-3578. CrossRef Medline

Porteous R, Petersen SL, Yeo SH, Bhattarai JP, Ciofi P, de Tassigny XD, Colledge WH, Caraty A, Herbison AE (2011) Kisspeptin neurons coexpress met-enkephalin and galanin in the rostral periventricular region of the female mouse hypothalamus. J Comp Neurol 519:3456-3469. CrossRef Medline

Qiu J, Nestor CC, Zhang C, Padilla SL, Palmiter RD, Kelly MJ, Rønnekleiv OK (2016) High-frequency stimulation-induced peptide release synchronizes arcuate kisspeptin neurons and excites GnRH neurons. eLife 5:e16246. CrossRef Medline

Rau AR, Hentges ST (2017) The relevance of AgRP neuron-derived GABA inputs to POMC neurons differs for spontaneous and evoked release. J Neurosci 37:7362-7372. CrossRef Medline

Ren J, Qin C, Hu F, Tan J, Qiu L, Zhao S, Feng G, Luo M (2011) Habenula "cholinergic" neurons co-release glutamate and acetylcholine and activate postsynaptic neurons via distinct transmission modes. Neuron 69: 445-452. CrossRef Medline

Roa J, Castellano JM, Navarro VM, Handelsman DJ, Pinilla L, Tena-Sempere M (2009) Kisspeptins and the control of gonadotropin secretion in male and female rodents. Peptides 30:57-66. CrossRef Medline

Schöne C, Burdakov D (2012) Glutamate and GABA as rapid effectors of hypothalamic "peptidergic" neurons. Front Behav Neurosci 6:81. CrossRef Medline

Schöne C, Apergis-Schoute J, Sakurai T, Adamantidis A, Burdakov D (2014) Coreleased orexin and glutamate evoke nonredundant spike outputs and computations in histamine neurons. Cell Rep 7:697-704. CrossRef Medline

Semaan SJ, Murray EK, Poling MC, Dhamija S, Forger NG, Kauffman AS (2010) BAX-dependent and BAX-independent regulation of Kiss1 neuron development in mice. Endocrinology 151:5807-5817. CrossRef Medline

Skrapits K, Borsay BÁ, Herczeg L, Ciofi P, Liposits Z, Hrabovszky E (2015) Neuropeptide co-expression in hypothalamic kisspeptin neurons of laboratory animals and the human. Front Neurosci 9:29. CrossRef Medline

Smith JT, Popa SM, Clifton DK, Hoffman GE, Steiner RA (2006) Kiss1 neurons in the forebrain as central processors for generating the preovulatory luteinizing hormone surge. J Neurosci 26:6687-6694. CrossRef Medline

Spergel DJ, Krüth U, Hanley DF, Sprengel R, Seeburg PH (1999) GABA-and glutamate-activated channels in green fluorescent protein-tagged gonadotropin-releasing hormone neurons in transgenic mice. J Neurosci 19:20372050. CrossRef Medline

Stephens SBZ, Rouse ML, Tolson KP, Liaw RB, Parra RA, Chahal N, Kauffman AS (2017) Effects of selective deletion of tyrosine hydroxylase from kisspeptin cells on puberty and reproduction in male and female mice. eNeuro 4:ENEURO.0150-17.2017. CrossRef Medline

Tong Q, Ye CP, Jones JE, Elmquist JK, Lowell BB (2008) Synaptic release of GABA by AgRP neurons is required for normal regulation of energy balance. Nat Neurosci 11:998-1000. CrossRef Medline

Tritsch NX, Granger AJ, Sabatini BL (2016) Mechanisms and functions of GABA co-release. Nat Rev Neurosci 17:139-145. CrossRef Medline

van den Pol AN (2012) Neuropeptide transmission in brain circuits. Neuron 76:98-115. CrossRef Medline

Verhage M, McMahon HT, Ghijsen WE, Boomsma F, Scholten G, Wiegant VM, Nicholls DG (1991) Differential release of amino acids, neuropeptides, and catecholamines from isolated nerve terminals. Neuron 6:517524. CrossRef Medline

Vong L, Ye C, Yang Z, Choi B, Chua S Jr, Lowell BB (2011) Leptin action on GABAergic neurons prevents obesity and reduces inhibitory tone to POMC neurons. Neuron 71:142-154. CrossRef Medline

Wen S, Götze IN, Mai O, Schauer C, Leinders-Zufall T, Boehm U (2011) Genetic identification of GnRH receptor neurons: a new model for studying neural circuits underlying reproductive physiology in the mouse brain. Endocrinology 152:1515-1526. CrossRef Medline

Xenias HS, Ibáñez-Sandoval O, Koós T, Tepper JM (2015) Are striatal tyrosine hydroxylase interneurons dopaminergic? J Neurosci 35:65846599. CrossRef Medline

Yeo SH, Kyle V, Morris PG, Jackman S, Sinnett-Smith LC, Schacker M, Chen C, Colledge WH (2016) Visualisation of Kiss1 neurone distribution using a Kiss1-CRE transgenic mouse. J Neuroendocrinol 28. CrossRef Medline

Yip SH, Boehm U, Herbison AE, Campbell RE (2015) Conditional viral tract tracing delineates the projections of the distinct kisspeptin neuron populations to GnRH neurons in the mouse. Endocrinology 156:25822594. CrossRef Medline 